This article was published in Waste Management, 43, 460-484, 2015

http://dx.doi.org/10.1016/j.wasman.2015.06.006

\title{
Life cycle assessment of three different management options for spent alkaline batteries
}

Susana Xará ${ }^{a, \Uparrow}$, Manuel Fonseca Almeida ${ }^{b}$, Carlos Costa $b$

a Faculty of Biotechnology, Portuguese Catholic University, Rua Arquitecto Lobão Vital, Apartado 2511, 4202-401 Porto, Portugal

b Laboratory for Process Engineering, Environment, Biotechnology and Energy, Faculty of Engineering, Porto University, Rua Dr. Roberto Frias, 4200-465 Porto, Portugal

\begin{abstract}
The potential environmental impact of Landfilling, Incineration and Recycling of spent household alkaline batteries collected in continental Portugal was compared using LCA methodology and the Recipe Impact Assessment method. Major contributors and improvement opportunities for each system were identified and scenarios for 2012 and 2016 legislation targets were evaluated.

For 13 out of the 18 impact categories, the Recycling system is the worst alternative, Incineration is the worst option for 4 and Landfill is the worst option only for one impact category. However if additionally in each system the recovery of materials and energy is taken into account there is a noticeable advantage of the Recycling system for all the impact categories.

The environmental profiles for 2012 and 2016 scenarios (25\% and $45 \%$ recycling rates, respectively) show the dominance of the Recycling system for most of the impact categories.

Based on the results of this study, it is questioned whether there are environmental benefits of recycling abroad the household alkaline batteries collected in continental Portugal and, since the low environmental performance of the Recycling system is particularly due to the international transport of the batteries to the recycling plant, is foreseen that a recycling facility located in Portugal, could bring a positive contribution to the environmental impact of the legislation compliance.
\end{abstract}

\section{Introduction}

The European legislation regarding waste is based on Framework Directive, Directive 2008/98/EC of the European Parliament and of the Council of 19 November 2008, that "lays down measures to protect the environment and human health by preventing or reducing the adverse impacts of the generation and management of waste and by reducing overall impacts of resource use and 
improving the efficiency of such use" (Official Journal of the European Union, 2008).

This Directive provides in Article 4 that the traditional waste hierarchy "shall apply as a priority order in waste prevention and management legislation and policy", and that when applying such hierarchy, "Member States shall take measures to encourage the options that deliver the best overall environmental outcome. This may require specific waste streams departing from the hierarchy where this is justified by life-cycle thinking on the overall impacts of the generation and management of such waste" (Official Journal of the European Union, 2008). Thus, although recycling is a hierarchically preferential option than energy recovery or landfilling it is important to know, for certain waste flows, the environ- mental loads associated with the different options to assess whether it is environmentally advantageous to comply with that hierarchy. In the environmental impact analysis of these options, it should be considered not only the treatment processes itself (recycling, incineration and landfilling) but also all other implications of those, such the transportation, the production of energy and auxiliary materials, etc., thus, applying the life cycle perspective to such analysis, i.e. analyzing the environmental impact from the origin of the waste to its final disposal or until the products resulting from its treatment are an integral part of the environment.

For some wastes, such as for alkaline batteries, that are part of the waste flow of batteries and accumulators, additional reasons motivate and justify this kind of assessment: (1) The flow of waste batteries and accumulators includes a wide range of products both in structural terms - from button batteries to industrial batteries - and in composition and hazards to the environment of their constituents - from the alkaline and zinc carbon batteries, considered lowpolluting until those that contain substances with recognized negative effect on the environment such as Mercury, Lead and Cadmium (Commission of the European Communities, 2003). The mandatory collection and recycling rates provided under current legislation (minimum of $25 \%$ by 2012 and $45 \%$ by 2016) applies to all portable batteries (and not just to those classified as hazardous as it was in previous legislation) not due to their hazards or potential environmental impact but because the collection schemes for all portable batteries have proven to be more efficient than separate ones for certain types of batteries, because consumers have shown difficulty in identifying and thus to separate the non-hazardous and hazardous batteries. (2) Moreover, despite being defined European targets for separate collection and recycling of all types of portable batteries (Official Journal of the European Union, 2006), that includes alkaline batteries, the batteries that are not separately collected will be sent for incineration or landfilling. The literature refers situations where, although the batteries were separately collected, they were sent to landfill, as happened at least in Sweden and Germany (Commission of the European Communities, 2003). In compliance with the current legislation these situations should no longer be possible since it obliges that all batteries collected separately are recycled. (3) Additionally, in the justification of the current legislation in the field of batteries, it is recognized the lack of scientific knowledge, or at least 
specific data and in particular of LCA studies (Commission of the European Communities, 2003) that fully support the guidelines adopted.

The awareness of governs about the impact of management alternatives for spent batteries has led to quite extensive studies done in some European countries such as the United Kingdom (ERM, 2006), Belgium (Briffaerts et al., 2006, 2009) and the Netherlands (AOO, 2002a,b). The European Commission has also promoted the development of knowledge in this field (European Commission, 2009).

The ERM study arose after the adoption by the EU Council of Ministers, of the proposed directive on batteries and accumulators. It was commissioned by the UK Department for Environment, Food and Rural Affairs (Defra). The objective of the study is to inform about the costs and benefits of various options to implement, in the UK, the collection and recycling of portable batteries as provided in the draft directive. This study uses the LCA with a subsequent economic evaluation of battery management alternatives between 2006 and 2030. It shows that the increase of battery recycling is beneficial to the environment due to the recovery of metals; however, it is done at a significant financial cost when compared with the elimination. Additionally estimations show that the implementation of the proposed directive will result in a significant increase in battery waste management costs, but with some savings in financial costs if environmental and social aspects are quantified (ERM, 2006).

In the study from Briffaerts et al. (2006, 2009) two hydrometallurgical (Revabat and Revatech) and two pyrometallurgical (Batrec and Valdi) treatment scenarios are

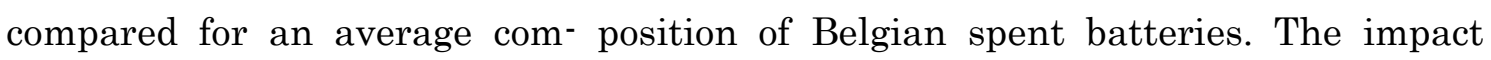
assessment method Eco-indicator 1999 was used. According to the study, none of the treatment scenarios have a better or worse overall performance than the others. Each option has specific advantages and disadvantages.

A study was conducted in 2002 comparing the life cycle of four waste treatment options for batteries collected in the Netherlands (AOO, 2002a,b): Batrec, Valdi, Nedstaal (production of steel in electric arc furnace) and Zimaval (hydrometallurgical treatment that produces metallic zinc). The CML impact assessment method was used. The study concluded that Valdi and Batrec have a better performance than Nedstaal and Zimaval. For Valdi, the main environ- mental impact was due to mercury emissions because in 2002 the facility was not equipped with activated carbon filter (AOO, 2002a). For Batrec, the results were negatively influenced by the relatively high production of waste.

The study, sponsored by the European Commission (European Commission, 2009) is an excellent compilation of data and technical information about battery recycling.

Despite the existence of some studies in this area, their results may not be extrapolated from country to country or even from region to region not only due to the specificities of the processes, but also to the characteristics of the countries/regions in question, such as the electric matrix.

Thus, it seems justifiable and helpful an evaluation of the environmental 
burdens of management alternatives for spent alkaline batteries, the portable batteries most commonly used in Portugal, which is the objective of this work. The methodology chosen for this study is the Life Cycle Assessment according to ISO 14040 (ISO, 2006a) and ISO 14044 (ISO, 2006b) standards. The following description fulfils the requirements of these standards with limits on extension and with some adaptations in structure requested by a scientific paper.

\section{Goal and scope definition}

\subsection{Goal definition}

The reason for this study is to know the potential environmental impacts associated with three management alternatives for spent household alkaline batteries collected in continental Portugal with the following final destinations: (1) landfilling; (2) incineration and (3) recycling.

The results of the study and the information developed in its implementation (in particular the knowledge of the processes involved and the identification and quantification of associated inputs and outputs) have several applications from which we can highlight a few, explored in this paper. On one hand the study allows to compare the environmental performance of these three management alternatives taking into account various environmental issues, defined by the impact categories and the different compartments of the environment i.e. air, water and soil. On the other hand, it allows identifying the origin (at the inventory level) of the most significant environmental burdens and, consequently, the environmental advantages and disadvantages of each alternative thus allowing the identification and definition of improvement opportunities for each one. It was also possible to study two scenarios of spent alkaline batteries management in continental Portugal, considering legislation targets for batteries collection and recycling in 2012 and 2016, in which the three mentioned options coexist. The 2012 and 2016 scenarios consider respectively: (i) recycling - 25\% and 45\%; (ii) landfill $-56 \%$ and $41 \%$ and (iii) incineration - $19 \%$ and $14 \%$. The recycling rates of $25 \%$ and $45 \%$ correspond to the limits set by the legislation in force (Xará et al., 2014).

This study is intended to all those interested in knowing the comparative potential environmental impact of the options studied, and in this particular to the members of the entities involved in the definition of environmental policies and the management of these wastes. It is also intended to all whom it may concern to know the environmental advantages and disadvantages (opportunities for improvement) of each alternative such as professionals involved in the different processes considered.

Since this study is part of a research project it is expected that the results are used in comparative statements for public disclosure, particularly in technical and scientific communications that implies, according to ISO 14040, specific requirements in its dissemination. 


\subsection{Scope definition}

\subsubsection{Systems under study}

The life cycle of the systems under study starts when the consumers discard/deposit spent batteries and terminates when emissions associated with the final destination of these batteries become an integral part of the environment.

In this study the reference situation of Continental Portugal is analyzed, considering the year 2012, the latest year for which data to characterize the MSW management systems are available. In 2012 the 278 municipalities of continental Portugal were organized into 23 systems with MSW management infrastructures ensuring an appropriate final destination for the waste produced in their area (APA, 2014a). Each system has at least a landfill, in a total of 34 landfills, but in two the incineration of MSW is the pre- dominant option and landfilling is only used during the incinerator maintenance periods or in case of failure. Thus, in Continental Portugal, there are two incineration plants and 32 landfills receiving mixed MSW daily. In 2012, from the total MSW generated, 18.2\% was incinerated and 53.6\% landfilled (APA, 2013a).

Despite the existence of selective collection schemes for spent alkaline batteries in continental Portugal, a significant amount is still discarded with the mixed household waste. In the first case the batteries will be sent for recycling abroad (Xará et al., 2014) and in the second to landfill or incineration according to the MSW management system of the municipality. In both cases, the collection will be the responsibility of the municipality (or a company contracted by it) and may include the storage in a Transfer Station prior to the delivery to the landfill, the incineration or to the location from where the batteries will be sent to recycling. Both the landfill and the incineration comprise specific systems for emission treatment: the leachate and landfill gas from the land- fill and the air emissions from the incineration.

The systems under investigation are therefore the three options for spent household alkaline batteries management:

System 1: Mixed deposition/collection + Landfilling.

System 2: Mixed deposition/collection + Incineration.

System 3: Selective disposal/collection + Recycling.

Each system will be identified in this work for the correspondent final destination. They are depicted in Fig. 1 and briefly described below.

2.2.1.1. System 1: Landfilling. In this case consumers discard their spent batteries in the mixed household waste. No specific type of containers is used for packing these residues in the production site. Consumers usually use shopping plastic bags or specific trash bags. After that, at the municipal level, there are containers or, less commonly, the bags are simply placed on the sidewalk for collection. The 
mixed household waste is then collected and transported to the landfill of the MSW management system to which the municipality belongs eventually through a Transfer Station. The landfilling can be preceded by a mechanical and biological waste treatment.

For the characterization of the landfills in operation in 2012 in continental Portugal the respective environmental licenses were consulted (APA, 2014b), only available for 26 of the 32 landfills (see Section 2.2.1).The characterization was focused on quantifying the volume $\left(\mathrm{m}^{3}\right)$, the installed capacity (ton) and the resource consumption (water, electricity and diesel) of an average landfill in continental Portugal. Also the different typologies of landfill gas and leachate treatment were investigated. The characterization of such landfills is shown in Table 1 (columns 1 and 2) in Appendix A. In Fig. 2 the landfilling system considered in this study is out- lined with the identification of the different processes and the main inputs and outputs.

During the reception and disposal of waste in a landfill, process water is consumed for drinking, showers and toilets, washes (including pavements, vehicles and wheels), for the irrigation systems and fire. This water may come from public network or from own captures. The diesel is consumed in vehicles and equipment and the electricity primarily for lighting but also in other applications as heating office buildings in winters.

The captured landfill gas is simply burned in flares or used for energy recovery, particularly for electricity production. The landfill gas not captured mainly the one resulting from collection inefficiency, is released into the environment. The production of landfill gas (captured or not) involves air emissions. The leachate produced during 100 years after the closure of the landfill is subjected to a treatment, which generates sludge sent to incineration. After this period, the leachate produced is directly released into the environment.

2.2.1.2. System 2: Incineration. In this system the collection process is at all similar to the previous one but the treatment process is incineration and therefore the waste is collected and transported to the incineration plant of the MSW management system to which the municipality belongs.

The two incineration plants existing in continental Portugal are in operation since 2000. Both are mass-burn incinerators with energy recovery. One of the units belongs to the MSW management system denominated Valorsul, located in Lisbon, the country capital, and the other belongs to Lipor, the system located in the Porto region, in the North, the second most important city of the country.

To determine the inventory of the alkaline batteries incineration in Portugal these two incinerators were firstly characterized both in terms of process technology and of its operation concerning resource consumption and emissions in 2012 for which environ- mental licenses data and official reports were used (APA, 2014c,d). In that year Lipor incinerated 391,623 ton of mixed MSW and Valorsul 498,275 ton. Both units are equipped with: (i) magnetic separation of ferrous scrap in the bottom ash; 
(ii) selective non-catalytic nitrogen oxides ( $\mathrm{NO} x$ ) reduction (SNCR) system by injection of an aqueous solution of ammonia or urea at the bottom of the combustion chamber; and, (iii) gas treatment system comprising a reactor and a bag filter - in the reactor the neutralization of acid gases ( $\mathrm{SO} 2, \mathrm{HCl}$ and $\mathrm{HF})$ takes place in a semi-dry process by injection of an aqueous lime milk solution and there, it is also injected activated carbon for the removal of dioxins, furans and heavy metals, especially mercury. The amount of solution injected to reduce $\mathrm{NO}_{x}$ emissions depends on the thermal load of the furnace and on the $\mathrm{NO} x$ amount in the flue gas (APA, 2014d). The aqueous lime solution is usually prepared from lime, $\mathrm{Ca}(\mathrm{OH})_{2}$ (Bicocchi, 1998).

Fig. 3 outlines the Incineration system considered in this study with the identification of the different processes and the main inputs and outputs. From the incineration process, air emissions and solid waste (bottom ash and fly ash) result. The air emissions are treated as referred before. The bottom ash, after the removal of ferrous scraps, is sent to a landfill of non-hazardous waste. The fly ash and the residues from the gas treatment are stabilized/solidified with cement and sent to a ash landfill. The leachate from the bottom ash and fly ash landfills results in short-term and long-term water emissions.

2.2.1.3. System 3: Recycling. In this case, consumers place their own spent batteries in specific carton containers placed in certain institutions (supermarkets, schools and others) or in plastic containers existing on streets close to the ones for selective deposition of MSW. Hence, they are collected, packing in the specific carton containers if previously collected in other system and transported to the sorting unit from where they are then sent for recycling abroad. In the present study the recycling process Fernwärme Wien in Austria is considered. This recycling process was chosen because it is the one that showed the best environmental performance in a study where different processes were evaluated (Xará et al., 2014) and it is the one for which primary data (directly from the recycling company) was obtained.

The plant is situated at Fernwärme Wien's hazardous waste incineration plant Simmeringer Haide, Vienna, which incinerates 100,000 tpy of hazardous industrial waste and 180,000 tpy of sewage sludge. It processes about 3000 tpy of spent batteries on base of a 7000 hpy continuous operation. Fed batteries are mainly zinc carbon batteries, alkaline batteries and mixtures. The delivered batteries are dumped into a feeding bin (Fig. 4) and via a dosing belt conveyors and a vertical conveyor the batteries are continuously fed into the rotary kiln. Ignited by small amounts of fuel oil the batteries are treated at temperatures of approximately $650{ }^{\circ} \mathrm{C}$ for about $1 \mathrm{~h}$. During this process, the spent batteries disintegrate; carbon, zinc and manganese are oxidized; and heavy metals leave the kiln with the dust fraction of the flue gas. After exiting the rotary kiln and passing the post-combustion and separation chamber the remaining dry bulk material is discharged using a cooling screw. The cold material is then fed to the shredder by a bucket elevator. The shredded solid material is separated into a 
fine and a coarse fraction using a sieving machine. The coarse fraction is fur- ther separated by a magnetic separator into a magnetic (scrap metal) and a nonmagnetic fraction (zinc/manganese oxide).

The off gas passes a hot cyclone to remove most of the entrained solids and is then cleaned in a three-stage flue gas treatment sys- tem. As, because of the low temperature, combustion might not have been complete, and the off-gas contains hazardous components such as mercury, the off-gas is fed into one of the hazardous waste rotary kilns for final post combustion at $1200^{\circ} \mathrm{C}$. Afterwards, it passes the same multi-stage gas cleaning system including an electrostatic filter, scrubbers, activated coal filter and nitrogen oxide removal (SCR) as the flue gas out of the main hazardous waste treatment plant for final cleaning. This plant interconnection ensures that all emission limit values given by legal regulations can be met. The process water used in the scrubber's plant is continuously removed by fresh water. The waste water is collected by the wastewater collection system from where it is pumped into the wastewater treatment station of the hazardous waste incinerator and treated together with the mainstream by stepwise precipitation using iron chloride, lime and TMT 15.

The scrap is sent to one of the Austrian steel plants. To separate clean scrap, two powder fractions are produced both containing a similar percentage of zinc and manganese that are further processed in a Waelz kiln process where zinc is recovered for use in the metal industry and a vitreous slag is formed which can be used in underground construction (Xará et al., 2014).

\subsubsection{Systems functions}

The main function of the studied systems is the management of spent alkaline batteries after their delivery/deposition by the consumer. In the Recycling system there is additionally material recovery (steel, zinc and vitreous slag); in the landfilling energy recovery takes place; in the incineration process there are both energy and material recovery (steel scrap from bottom ash). In this study, the quantification of such recovered flows and the inherent environmental advantage is presented separately in order to evaluate its effect in the respective system analysis.

\subsubsection{Functional unit and reference unit}

In this study, the functional unit is the treatment of a certain number of batteries carried to certain final destination - landfilling, incineration or recycling. As reference unit, an amount of $1000 \mathrm{~kg}$ of household spent alkaline batteries, size AA, which corresponds to about 42,553 units (assuming an average weight of $23.5 \mathrm{~g} / \mathrm{battery}$ ) was used.

\subsubsection{Systems boundary}

For each system the processes that are part of the life cycle of the waste are considered - from delivery/deposition by the consumer until the resulting emissions become an integral part of the environment. 
In Figs. 2 and 3 the individual systems of Landfilling and Incineration, respectively, are shown schematically, representing the processes considered in the study and their inter-relationships as well as identifying their main inputs and outputs.

For system 1 - Landfilling (Fig. 2) - the following processes are considered:

- Reception and waste disposal.

- Landfill gas treatment.

- Leachate treatment (only for the leachate occurring over the first 100 years).

- Incineration of sludge resulting from the leachate treatment.

- Landfilling of bottom ash and fly ash (produced during the incineration of the sludge).

For system 2 - Incineration (Fig. 3) - the following processes are considered:

- Reception and waste burning.

- Gas treatment.

- Bottom ash de-scrapping.

- Fly ash and gas treatment residues stabilization/solidification.

- Landfilling of bottom ash and solidified residues and treatment of their leachates.

For system 3 - Recycling - the recycling process in Austria, previously studied by the authors (Xará et al., 2014) was considered. The processes included are grouped into: containers manufacture; distribution of empty containers; batteries collection and sorting; batteries international transport for recycling and batteries recycling (Fig. 4).

The production of materials and energy needed to the previous processes are also considered, so that in-flows and out-flows are elementary. Any exception to this approach is justified in the inventory section. Transport distances are listed in the inventory. Recovered materials are likely to replace virgin resources and are usually considered environmentally beneficial. However, among LCA practitioners, there is no consensus about the system to which this environmental benefit should be allocated - to the system in which the material is recovered or to the one in which it is used replacing a virgin material. In this study, recovered materials are identified in the inventory of each system and considered in the impact assessment phase separately so allowing the evaluation of its effect on the overall result of the system. The same approach was applied to energy recovery in landfill and incineration.

\subsubsection{Data requirements and data quality requirements}

Given that the purpose of this study is focused on evaluating the potential environmental impact of alternatives to manage spent alkaline batteries collected in continental Portugal, it is at all required that the data used reflect this reality. Thus, 
in characterizing and modeling each process, primary data, both laboratory and from entities involved in that waste management, and secondary data, obtained in official and scientific publications were used. When defining the inventories, published data and the Ecoinvent database (Ecoinvent, 2010) were used. In the inventory of each system the origin of the data used is indicated.

\subsubsection{Allocation procedures}

In the present study allocation procedures have been used particularly in the definition of the inventories for the different processes. These are identified in the inventory section or in the bibliographic references supporting the inventory of each process.

\subsubsection{Impact categories and impact assessment methodology}

Considering the objective of the study, the method Recipe 2014, version 1.11 (http://www.lcia-recipe.net) was used for the impact assessment. In detail, indicators at the midpoint level and the Hierarchist perspective were chosen. The impact categories addressed and their respective units, abbreviations and area of protection are presented in Table 2 . These impact categories belong to the areas of protection of Human health, Ecosystem and Resources.

\subsubsection{Interpretation}

Since we intend to compare the three management alternatives for the spent batteries, the interpretation include the comparison of results for each impact category, in order to infer about the effect of each alternative on each environmental issue. Additionally, for each system, the processes that most contributes to the result in each impact category are identified and are seen as improvement opportunities.

As mentioned in the goal definition (Section 2.1), the interpretation also includes the analysis of two scenarios of spent alkaline batteries management in continental Portugal where the three options coexist. They are denominated 2012 and 2016 and were established considering that respectively $25 \%$ and $45 \%$ of discarded batteries were selectively collected and recycled while the remaining were subjected to the landfilling or incineration processes in the same proportion that was reported for mixed MSW in 2012 (see Section 2.2.1). The 2012 and 2016 scenarios consider respectively: (i) recycling $-25 \%$ and $45 \%$; (ii) landfill $-56 \%$ and $41 \%$ and (iii) incineration $-19 \%$ and $14 \%$. The recycling rates of $25 \%$ and $45 \%$ correspond to the limits set by the legislation in force (Xará et al., 2014).

\subsubsection{Assumptions, value choices and optional elements}

To carry out the present study a number of assumptions were considered. In each situation they are presented in the inventory section. In the Interpretation (Section 2.2.8), when identifying the processes that most contribute to the result of each management alternative for each impact category the influence of the assumptions on the final results was also verified. 


\subsubsection{Limitations}

The characterization of the systems under study, their analysis in terms of inventory, impact assessment and interpretation are associated with the previously mentioned assumptions. Thus, for the limitations of the study it can only be added that the result relates to the systems described in this paper taking into account the assumptions referred and the knowledge limitations reflected in the databases and in the impact assessment method used.

\subsubsection{Type of critical review}

Since the present study involves the comparison of batteries management alternatives and it is planned to publish its results, the critical review was conducted by experts not involved in the study but stated as co-authors of this research paper. All the comments were discussed and incorporated in the present paper.

\section{Life cycle inventory}

For each system under study, data for description and characterization of all the processes identified within its border was collected (Section 2.2.7). This characterization includes identification and quantification of the inputs and outputs and the following categories of data were considered:

- Inputs of energy, raw materials and auxiliaries.

- Products, co-products and waste.

- Emissions to air, discharges to water and soil.

Primary data were used - both from laboratory tests and from the entities involved in the waste management, and secondary data - obtained from official publications and also from the data- base Ecoinvent (Ecoinvent, 2010).

Both in the processes of landfilling and incineration, the alkaline batteries are part of a mixture of waste which includes a wide variety of materials and articles. In this study, through the modeling of such processes, the resources and emissions that are associated with this waste stream were estimated; some of these inputs and outputs are allocated to this stream based on its mass and other based on some of their particular properties, particularly its composition.

\subsection{Batteries composition}

The batteries considered in this study were characterized in lab- oratory (Almeida et al., 2006) in terms of its structural components and their material identification, dry weight, moisture content, ash content, higher heating value. The elemental composition of the different components was also determined. This and other characteristics necessary in the present study are presented in Table 3 (in Appendix A) where are also indicated the calculations and/or estimations done. 


\subsection{Landfilling}

The inputs and outputs of the Landfill system for disposal of $1 \mathrm{~kg}$ of target batteries were determined using the model pro- posed by Doka (2009). In this model various parameters relating to landfills are considered, some of which were compared with the corresponding to the landfills of continental Portugal. The parameters of water consumption and gas treatment have been changed to better match the reality in Portugal. The others were considered appropriate (see Table 1, in Appendix A). Although in Portugal does not exist incineration of sludge from landfill leachate treatment, this process was considered in this study because this is considered a good practice which may be adopted in the country and as such seen as a good baseline. The waste resulting from this incineration is then landfilled in slag compartments (bottom ash landfill) and residual material landfill (fly ash and residues from gas treatment landfill). The parameters of these processes were not changed.

This model is based on the definition of transfer coefficients (TK) for each element, which when applied to the composition of the batteries allow to quantify the different resulting emissions that are divided into short-term (occurring over the first 100 years) and long-term (occurring from 100 to 60,000 years after the waste placement) (Doka, 2009). The short-term emissions include gas and leachate emissions that will be subjected to treatment; the long-term emissions are only long-term leachate in the groundwater (Fig. 2). On determining the emissions, for some elements their speciation is considered because the different compounds have different environmental burdens. In the particular case of gaseous emissions of carbon compounds $(\mathrm{CO}, \mathrm{CO} 2$ and $\mathrm{CH} 4)$ emissions from fossil and biogenic origin are distinguished.

The short-term transfer coefficients, both for the gas (TK short-term gas or simply TK gas) as for the leachate (TK short-term leachate) are obtained (equations 1 and 2, respectively) by the product of Elemental degradation rates (De) for the waste in study (which is obtained from the degradability of each component of the batteries in 100 years and its elemental composition), the release factor (re), and the share (\%) of element transferred to gas and leachate respectively. The degradability of each component of the batteries in 100 years and its elemental composition are reported in Table 3, in Appendix A; the release factor and the share of element transferred to the gas and leachate are obtained from bibliographic references (Doka, 2009). These parameters are shown in Table 4, in Appendix A.

TK short-term gas $=$ De $\times$ re $\times \%$ gas

TK short-term leachate $=$ De $\times$ re $\times$ \%leachate

The degradability is homogeneous, i.e. it is the same for all elements of the same matrix (the same component of the batteries) but the release factor is different for 
each chemical element (Doka, 2009).

The transfer coefficient for the long-term emissions (TK leachate long-term) addresses further degradation and emissions after 100 years.

In applying this model, the emissions resulting from the degradation of the defined batteries (emissions to leachate) were com- pared with the results of several leaching tests previously performed (Xará et al., 2009, 2013). Those results were used to estimate the degradability of each component of the batteries whose values are presented in Table 3, in Appendix A.

In Table 5, in Appendix A, inputs and outputs for the landfilling of $1 \mathrm{~kg}$ of batteries, including the data used, the calculation, the assumptions, the allocation processes and the data source for the inventory are presented.

\subsection{Incineration}

When modeling the incineration process, the batteries composition previously presented in Section 3.1 and Table 3 (in Appendix A) was considered. Beyond the elemental composition of each component, the heating value, the share of metallic/recyclable $\mathrm{Fe}$ and the share of biogenic $\mathrm{C}$ are included and each component is also classified as burnable or non-burnable, i.e. inert (Table 3 , in Appendix A).

The modeling is based on the definition of transfer coefficients that quantify the distribution of each chemical element present in batteries between the outputs of the incineration process. It is generally considered that inert components go completely into the bottom ash (Doka, 2009) and that for burnable components there will be a distribution between the incineration outputs, in this case (incineration with semi-dry gas treatment system) air emissions, bottom ash and fly ash.

Given the specificity of the product under analysis, the domestic alkaline batteries, the transfer coefficients used in this study were developed for this purpose based in laboratory tests, described in Almeida et al. (2009), complemented by data from literature. Those transfer coefficients are shown and explained in Table 6.

The resulting bottom ash is additionally subjected to a de-scrapping process where ferrous metals are removed for recovery before it is sent to a landfill. The fly ash (and the residues from the gas treatment) are stabilized/solidified with cement and also sent to a landfill. In both cases the compound emissions, particularly due to the oxidation, are considered. The gaseous emissions (raw gas) is subjected to a treatment process where the transfer of some elements to the fly ash occurs, together with residual $\mathrm{Ca}(\mathrm{OH})_{2}$ and charcoal used in this treatment. The speciation of elements is also considered.

To estimate the resulting leachate emissions from landfilled bottom and fly ash, transfer coefficients from the literature that are established for short and long term were used (Doka, 2009) which are presented in Table 7. Applying these coefficients to each ash element allows estimating its content in leachates from short and long term respectively. 
In the various models developed to assess the environmental impact of the incineration process in LCA studies of products there seems to be concordance on the distinction between resource consumption and emissions related to the process and to the product:

- process-specific properties are modeled as being independent of the intrinsic properties of the product and typically modeled as following the amount of the product;

- product-specific properties are partially or fully determined by intrinsic properties of the product, most frequently the material composition (Erichsen and Hauschild, 2000).

Thus, the process-specific inputs are expressed per tonne of waste while product-specific ones are expressed per a quantity or content of a substance in the product (waste).

From the waste incineration results $\mathrm{NO} x$ and other $\mathrm{N}$-containing air emissions; $\mathrm{NH} 3, \mathrm{~N}_{2} \mathrm{O}$ and $\mathrm{CN}$. $\mathrm{NO} x$ emissions are considered process and product specific, i.e., part is considered to be formed from nitrogen in combustion air (thermal $\mathrm{NO} x$ or process-specific $\mathrm{NO} x$ ) and the other part from nitrogen from waste (fuel-NO $x$, waste-specific $\mathrm{NO} x$ or product-specific $\mathrm{NO} x$ ) or more precisely, from the nitrogen in the waste that is transferred to the raw gas and can actually form these emissions (Doka, 2009).

In this study a share of $75 \%$ fuel $\mathrm{NO} x$ and $25 \%$ of thermal $\mathrm{NO} x$ it is assumed (Erichsen and Hauschild, 2000; EEA, 2009). Furthermore, as the Incineration system includes a De-NO $x$ SNCR process, NH3 emissions are also allocated in the same way and $\mathrm{N}_{2} \mathrm{O}$ emissions are considered fuel-specific (Doka, 2009). No emissions of HCN were considered due to lack of data.

Although it is known that the use of activated carbon has a beneficial effect in removing $\mathrm{Hg}$ (and possibly other metals) from the gas, no further removal of mercury with charcoal was considered because the modeled transfer coefficient for $\mathrm{Hg}$ emission to air (4.1\%) is close to that reported by Erichsen and Hauschild (2000) (4.8\%) and much lower than that of Koehler et al. (2011) (17\%). In the slag, the modeled mercury value is higher than the one reported in both references.

In Table 8, inputs and outputs for the incineration of $1 \mathrm{~kg}$ of batteries, including the data used, the calculation, the assumptions, the allocation processes and the data source for the inventory are presented.

\subsection{Recycling}

The inventory for the Recycling system is the one from Austria, Fernwärme Wien, presented in Xará et al. (2014). 


\section{Life cycle impact assessment (LCIA)}

As already mentioned the method of impact assessment Recipe 2014 with results at midpoint level and for the Hierarchist perspective (Goedkoop et al., 2013) was used. For that the different elementary inputs and outputs of the inventory of each system were classified and characterized for the different impact categories and taking into account the environmental compartment of concern that is shown in the respective inventory tables (Table 5, in Appendix A, for Landfill and Table 8 for Incineration system).

In Figs. 5-7 (orange columns) the results of the impact assessment for $1000 \mathrm{~kg}$ of batteries, for each impact category and for the three management alternatives are presented. The analysis of the results is made in the following Interpretation section. In this analysis the environmental benefits arising from the recovery of materials and energy in the processes involved, as shown in the inventories of their systems, was also considered (green columns). In Fig. 8 the results for each system and for each impact categories are compared with the result of the system with worse environ- mental performance, scale to $100 \%$.

For each system and for each impact category the processes or even the elementary streams that most contribute to its outcome were identified. This analysis is contemplated in Figs. 9-11, for Recycling, Incineration and Landfill systems, respectively, and allows the identification of improvement opportunities for each system for each impact category.

Scenarios for alkaline batteries management in continental Portugal in 2012 and 2016 assuming the quantities for each destination as referred to in Section 2.2.8, is shown in Fig. 12, without the inclusion of the environmental advantages resulting from the materials and energy recovery in each system. The analysis of the results is also made in the following Interpretation section.

\section{Interpretation}

\subsection{Comparison of management alternatives for each impact category}

The comparison of the management alternatives is firstly done without considering the energy/materials recovery (Figs. 5-7, orange columns).

For the impact categories of land transformation and occupation, for the Ecosystem protection area (Figs. 5 and 8) - Agricultural Land Occupation (ALO), Urban Land Occupation (ULO) and Natural Land Transformation (NLT) - the Recycling sys- tem has a significantly more negative impact than that of Landfill and Incineration systems.

For both the Terrestrial Acidification (TA) and Climate Change (CC) (Figs. 5 and 8), Recycling is again the system with the highest impact and Landfill with the lowest.

For the impact categories of ecotoxicity (Figs. 5 and 8) - Terrestrial Ecotoxicity 
(TET), Marine Ecotoxicity (MET) and Freshwater Ecotoxicity (FET) - the Recycling system presents a sig- nificant advantage over the other two systems for the aquatic toxicity, i.e. MET and FET while the Landfill has the best environmental performance for TET. For these categories, the Incineration is the worst option.

For the Freshwater (FE) and Marine eutrophication (ME) (Figs. 5 and 8) Recycling is the system with the worst performance for FE. For ME, Landfill and Recycling have similar impacts with slight dis- advantage of Landfill, and Incineration is the best option.

For the impact categories of Human health protection area (Figs. 6 and 8) Particulate matter formation (PMF), Photochemical oxidant formation (POF), Ozone depletion (OD) and Ionizing radiation (IR) - the Recycling system is also the most negative and Landfill and Incineration have better performance with advantage of Landfill for PMF, POF and IR. Incineration is the best system for OD.

For the Human toxicity (HT) (Figs. 6 and 8) the Recycling system presents a significant advantage over the other two systems and Incineration is the worst option despite the small difference to the impact from the Landfill.

For all the impact categories of Resources protection area (Figs. 7 and 8) Fossil depletion (FD), Metal depletion (MD), and Water depletion (WD) - the Recycling system has a significantly higher impact than the Landfill and the Incineration systems, both with impacts quite close but with predominance of Landfill in Fossil depletion and of Incineration in Metal and Water depletion. If additionally accounted for the recovery of materials and energy, under the conditions set out in their inventories, there is a noticeable advantage of the Recycling system for all the impact categories (Figs. 5-7, green columns).

\subsection{Improvement opportunities for each system}

In the analysis of improvement opportunities for the Recycling system (Fig. 9), through the identification of the processes that most contribute to its results, it is clear the influence of the trans- port, mainly in the impact categories from Ecosystem and Resources protection areas. In the impact categories of Human Health protection area there is also an important contribution of transport but the contribution of the recycling process could be considered more significant. The boxes production has meaningful results only for 3 impact categories related with land occupation and water consumption. The batteries collection and sorting appears with meaningful influence in Marine eutrophication.

The processes or even the elemental flows that most contribute to the displayed results were further identified, with the possible detail, by analyzing the inventories.

For the Agricultural land occupation (ALO), the impact of the Recycling system is mainly due to the boxes manufacturing processes (96\% of the total impact for this category) and particularly due to the paper production. For the other land categories the result obtained for the Recycling system is led by the contribution of the 
batteries international transport to the recycling unit; $33 \%$ and $39 \%$ respectively for ULO and NLT, in both cases due to the road land use. For ULO, the boxes manufacture is the second largest contribution (27\%) for the Recycling system result, also due to the paper production. For NLT it is the recycling process itself that contributes with $36 \%$, mainly due to the production of the fuel used in the process.

For the impact categories Terrestrial acidification (TA), Terrestrial ecotoxicity (TET), Marine eutrophication (ME), Climate Change (CC), Particulate matter formation (PMF) and Photochemical oxidant formation (POF), and Fossil depletion (FD) and Metal depletion (MD), the process that most contributes for the Recycling system result is the international transport of the batteries, $46 \%, 36 \%$, $56 \%, 45 \%, 49 \%, 56 \% 40 \%$ and $47 \%$, respectively (Fig. 9). This effect of the transport is mainly due to the emissions from the fuel use and also due to the lorry itself.

For all these categories in which transport has a predominant effect, and with the exception of $\mathrm{ME}$, the recycling process is the second most important contribution to the result, ranging from $18 \%$ (POF) to $39 \%$ (FD). The impact is mainly due to fuel and electricity consumption for TA, TET, PMF and POF; to electricity consumption for $\mathrm{CC}$; to fuel consumption for $\mathrm{FD}$ and to $\mathrm{FeCl} 3$ consumption for MD.

Concluding, for the Recycling system there is no doubt about the environmental effect of the use of fuel - in the transport and in the recycling process itself - and of electricity and $\mathrm{FeCl} 3$ consumption - in the recycling process.

Improvement opportunities for Incineration System are more varied (Fig. 10), i.e. a larger number of processes or elementary flows have been identified (16) that influence the outcome of this system in the different impact categories.

In the Agricultural land occupation there is a $87 \%$ contribution of the charcoal production, due to the use of soil. The bottom ash land- fill is the main contributor to the results for Urban land occupation (ULO) and Natural land transformation (NLT): for ULO predominates the effect of the specific burdens, i.e. the land occupation during the construction and by the landfill itself; for NLT the negative impact (positive value) due to the landfill construction (transformation of the land for the road network) is compensated by the transformation of the land after the landfill closure (negative value).

The result of the Incineration system for Terrestrial acidification (TA), Particulate matter formation (PMF) and Photochemical oxidants formation (POF), is due to the emissions of nitrogen oxides, thermal (44\%, 38\% and $45 \%$, respectively) and fuel $(30 \%, 26 \%$ and $31 \%$, respectively). Also the results for terrestrial ecotoxicity (TET) and Climate Change (CC) are predominantly due to air emissions from the incineration process itself: zinc (97\%) and fossil $\mathrm{CO}_{2}$ (88\%), respectively. The same applies for the Depletion of water, mainly due $(63 \%)$ to the water consumption in the process itself.

The long-term emissions to groundwater, resulting from bot- tom ash and fly ash landfills leachate (after 100 years), have pre- dominant contributions to the impact categories of Marine ecotoxicity (MET), Freshwater ecotoxicity (FET), Human Toxicity (HT) and Marine eutrophication (ME): emissions of $\mathrm{Cu}(37 \%)$ and 
Mn (29\%) for MET; Cu (38\%) and Zn (28\%) for FET; nitrates (19\%) for ME; and Mn (97\%) for HT. So it is noticed an important effect of these long-term environmental burdens resulting from the incineration of batteries.

For the impact categories of Freshwater eutrophication (FE) and Ionizing radiation (IR), the result is predominantly caused by the use of cement in the solidification of ash from the incineration: the cement production contributes with $40 \%$ to the result in IR and the environmental burdens associated with its landfilling con- tribute with $42 \%$ to the result of $\mathrm{FE}$.

From the bottom ash landfill result major environmental bur- dens for Ozone depletion (OD) and Fossil resources depletion (FD), respectively 37\% and 33\%, predominantly associated with the consumption of diesel and asphalt, respectively (Fig. 10).

Concluding the analysis so far made to the Incineration system, there is an important contribution of atmospheric emissions from the incineration plant itself, but also from the ground water long-term emissions associated to the bottom and fly ash landfills and from the resources used in such landfills as the cement, diesel and asphalt. Additionally, the incineration plant itself has a significant contribution (77\%) only for the metals depletion (MD).

In contrast, for the Landfill system (Fig. 11) there is a predominant effect of the construction and of the specific process burdens (independent of the waste to be treated) on the outcome of most of the impact categories. For 14 of the 18 impact categories analyzed, one of these two processes is dominant and only in four (MET, FET, HT and ME) their contributions are not significant.

For Marine and Freshwater ecotoxicities (MET and FET) and Human toxicity (HT) the contributions of long-term emissions of $\mathrm{Cu}$ (39\% for MET and FET), and $\mathrm{Mn}(97 \%$ for HT) in the groundwater dominate the impacts. These emissions result from the leachate of the MSW landfill and from the landfilling of bottom and fly ash produced by the incineration of the sludge resulting from the treatment of the short-term leachate. For ME the long-term emissions of organic nitrogen in the groundwater (63\%), resulting from the MSW landfill leachate, are the most important contribute.

For Urban land occupation (ULO), Natural land transformation (NLT), Terrestrial ecoxicity (TET), Freshwater eutrophication (FE), Climate change (CC), Photochemical oxidants formation (POF), Ozone depletion (OD), Ionizing radiation (IR), and Depletion of fossil (FD), metals (MD) and water (WD) resources, the effect of the landfill construction is predominant, ranging from $9 \%$ (for NLT) to $79 \%$ (for OD). In this cases the impact is predominantly due to: the land occupation and transformation by the road network for ULO and NLT; emissions associated with the fuel production used in the construction (for TET) and the use of this fuel (for $\mathrm{CC}$ and POF, respectively fossil $\mathrm{CO}_{2}$ and nitrogen oxides); the environmental burdens associated with the asphalt production (for OD and FD, respectively emissions and consumption); emissions associated with the production of excavators (FE); maintenance of the road network (for IR); transport-related consumption (for $\mathrm{MD}$ ) and the production of gravel (for WD). 
For the Agricultural land occupation (ALO), Terrestrial acidification (TA) and Particulate matter formation (PMF) the contribution of specific burdens from the landfill dominates. For ALO the impact is due to the land occupation by the landfill itself, while for TA and PMF is mainly due to nitrogen oxides emissions from the diesel used during the distribution and compaction of waste on the site.

Concluding, for the Landfill system it is observed a significant environmental effect associated with the construction of the land- fill itself and with the environmental burdens resulting from its operation. These burdens are however independent on the waste to be treated. Just for few impact categories of toxicity - MET, FET and HT, and additionally for marine eutrophication - there is a predominance of specific burdens of waste, due to long-term emissions in the groundwater.

\subsection{Analysis of the environmental profiles 2012 and 2016}

The environmental impacts of the scenarios were firstly calculated without considering the energy/material recovery.

The environmental profile of batteries management in continental Portugal in 2012 (Fig. 12) shows a major impact of the Recycling system for all the impact categories, except for TET, MET, FET, HT and ME, i.e. for all categories in which the Recycling system showed the worst performance in the comparative analysis with the other alternatives. For TET the impact of the incineration is prevalent while for the other categories (MET, FET, HT and ME), the impact of the Landfill dominates. Thus, since the European legislation established a minimum threshold for recycling, the improvement of the impact for this management system in Portugal must pass to intervene in these systems and in the impact categories listed.

In 8 of the 13 impact categories in which the Recycling system has the highest contribution to the outcome of the environmental profile, the process that most influences its outcome is the international transport of batteries (ULO, NLT, TA, $\mathrm{CC}, \mathrm{PMF}, \mathrm{POF}, \mathrm{FD}$ and $\mathrm{MD}$ ). For 4 of the other categories the recycling process is dominant (FE, OD, IR and WD) and only for one (ALO) the outcome is dominated by the boxes manufacture. To improve the environmental performance of batteries management in Portugal, in the studied conditions, it is therefore important to first consider the choice of a recycling process in a nearest location and/or an alternative transport system with less environmental impact.

For the categories in which the environmental profile is dominated by the impact of the landfill destination (MET, FET, HT and ME) it is noteworthy that only for ME the Landfill system is the worst in the comparative analysis with the other alternatives. For the others the Incineration and the Landfill systems have impacts of similar magnitude. The dominance of the Landfill in the analysis of this environmental profile results from the fact that the fraction of batteries which is sent to the landfill is significantly higher than the fraction sent to incineration. The performance improvement of the Landfill system may pass through a better 
control of long-term emissions into groundwater: copper and manganese, in case of MET and FET; manganese in case of HT; and organic nitrogen in case of ME.

The improvement, at the level of TET, of the implemented sys- tem, in which, as already mentioned, the contribution of incineration is prevalent, can pass through the control of zinc emissions to air in the incineration process.

The environmental profile for 2016 shows the same dominance of the Recycling system not only for all the categories referred to 2012, but also for TET and ME for whom this system overcomes the effect of the Incineration and of the Landfill, respectively. For all the categories the increase of the Recycling contribution is remarkable, especially for ULO, NLT, and TET this increase is more accentuated. For the other categories of toxicity (MET, FET and HT) the same proportion of the contribution between the Landfill and the Incineration remains with dominance of the Landfill. This pro- file reflects, as mentioned above, a possible situation for compliance with battery recycling targets set for 2016 . In this case, the improvement of its environmental performance can pass through the intervention in the processes, as previously mentioned in the analysis of the Profile for 2012. As in this situation the impact on TET and ME is dominated by the Recycling system, its reduction should be considered, which may involve the intervention in the international transport of batteries, the process that most con- tributes to the result of this system in these categories.

If the environmental benefits resulting from the recovery of materials and energy are considered the environmental benefit associated with materials recovered in the Recycling is noticeable and dominates the environmental profile. The main contribution to the advantages of the recycling system is due to the Waelz slag as a material replacing gravel/sand.

\section{Conclusions}

The 3 management alternatives for spent alkaline batteries collected in continental Portugal (landfilling, incineration and recycling in Austria) were compared using the LCA methodology and the impact assessment method Recipe 2014 at the midpoint level and the Hierarchist perspective. This method includes 18 impact categories of Ecosystem, Human health and Resources protection areas.

For the Landfill and Incineration systems, the final destination processes were modeled to estimate the resources consumption and the emissions (input and output flows) taking into account both the parameters of the processes in Portugal and the specific composition of the AA alkaline batteries, thereby obtaining specific results for this kind of waste. For the Recycling system primary data from the industry were used.

The environmental impact of the three systems were first calculated without considering the energy/material recovery and for 13 of the 18 impact categories analyzed (all the categories except TET, MET, FET, HT and ME) the Recycling system appears as the worst option. The Incineration option shows the highest impact for the TET and the Landfill is the worst system for ME. Finally, for MET, 
FET and HT the results for the Landfill and the Incineration systems are of the same magnitude.

Additionally, the processes that most contribute to the impact of the three systems have been identified. These should be considered to improve the waste battery management system.

Thus, for the Recycling system and the impact category Agricultural land occupation, improvement may be achieved in the boxes manufacture, particularly in the production of their paper components; for the other impact categories the performance improvement of the system pass through the intervention on the kind of international transport and/or in the recycling process itself, but there is a significant effect in more impact categories by acting on transport. In this system, it is of great importance the environmental effect of the use of fuel - in the transport and in the recycling process itself - and of the electricity and $\mathrm{FeCl} 3$ - in the recycling process.

For the Incineration system, there are several processes, resources and emissions that determine the outcome in the 18 impact categories considered, some of which are independent of the waste in study, i.e., that occur similarly for any other waste. There is an important contribution of air emissions from the incineration plant itself, but also of the ground water long-term emissions from bottom and fly ash landfills, and of resources for such landfills, as the cement, diesel and asphalt. For the impact categories to which the system showed a worse performance in a comparative analysis with the other two alternatives, the improvement may involve the intervention in zinc emissions to air (for Terrestrial ecotoxicity) and in the long term emissions of copper, manganese and zinc in ground water. These long-term emissions result from the leachate after 100 years of deposition of the resulting fly ash and bottom ash from incineration and the zinc air emissions result from the batteries incineration.

For the Landfill system, it is observed a significant environmental effect associated with the construction of the landfill and with the environmental burdens resulting from its operation, but independent of the waste to be treated. Just for the impact categories of toxicity - MET, FET and HT, and additionally for Marine eutrophication - there is a predominance of specific burdens of waste, long-term and for groundwater. Although this is not the system with the worst performance in the Marine and Freshwater water ecotoxicity and Human toxicity, it is the second worst system immediately after the Incineration and with the results of the same order of magnitude. In this case, the improvement may also pass through the long-term emissions of copper and manganese to ground water. These long-term emissions result from both the MSW landfill, as well as from the landfills of bottom and fly ashes from the incineration of sludge from the leachate treatment. Furthermore, for the impact category in which the Landfill is the worst performing system - Marine eutrophication - the improvement can pass through the reduction of emissions of organic nitro- gen resulting from the long-term leachate of the MSW landfill.

For all the impact categories of this method if further accounted for the recovery of 
materials and energy, under conditions set out in their inventories, the Recycling system appears with a notice- able advantage.

The environmental profile of the management of spent batteries from continental Portugal shows the dominance of the Recycling system for all the impact categories in which this system shows the worst performance in the comparative analysis of the three alternatives. For Terrestrial ecotoxicity the Incineration system shows the worst performance on that analysis and maintains a pre- dominant contribution to the environmental profile of 2012. But for the other categories (Marine and Freshwater ecotoxicity and Human toxicity), the low environmental performance of the Incineration is surpassed by the one of the Landfill system, because the amount of batteries with this final destination is larger and the relative impact of the two systems is similar, as mentioned before. For Marine eutrophication it is also the Landfill - the worst of the three systems in this category - that marks the result in the environmental profile for 2012.

The increase in the recycling rate, reflected in the environmental profile for 2016 will lead to the dominant influence of the Recycling system in Terrestrial ecotoxicity (formerly dominated by the Incineration system) and Marine eutrophication (formerly dominated by the Landfill system). For all categories the increase of the recycling contribution is remarkable, but for Urban land occupation, Natural land transformation and Terrestrial ecotoxicity this increase are more accentuated. For all these it is prevalent the effect of the international transport of batteries for recycling.

Based on the results from this study it should be questioned the environmental benefits of recycling abroad the household alkaline batteries collected in continental Portugal. Since the low environ- mental performance of the Recycling system is particularly due to the international transport of the batteries to the recycling plant, it is foreseen that a recycling facility located in Portugal, could bring a positive contribution to the environmental impact of the legislation compliance.

However, in the case of allocating the environmental advantage of materials and energy recovery to each respective system, recycling has a predictable beneficial and predominant effect.

The knowledge developed in this work may constitute a scientific support in future studies aiming at defining the best option for the management of this waste in light of the legislation; may also serve as an example and/or guidance to other works with the same objective to be done in other geographic and even Europewide areas; eventually, it may contribute to justification for future legislation; or even as a guide to studies to be done in other waste flows.

\section{Acknowledgments}

The authors acknowledge to FCT (Fundação para a Ciência e a Tecnologia) the Grant PRAXIS XXI/BD/20315/99. 
FCT Fundação para a Ciência e a Tecnologia

MINISTÉRIO DA EDUCAÇ̃̃o E CIÊNCIA

\section{References}

Almeida, M.F., Xará, S., Delgado, J., Costa, C., 2006. Characterization of spent AA household alkaline batteries. Waste Manage. 26 (5), 466-476. http://dx.doi.org/ 10.1016/j.wasman.2005.04.005.

Almeida, M.F., Xará, S., Delgado, J., Costa, C., 2009. Laboratory study on the behaviour of spent AA household alkaline batteries in incineration. Waste Manage. 29 (1), 342-349. http://dx.doi.org/10.1016/j.wasman.2008.03.011.

Althaus, H.-J., Chudacoff, M., Hischier, R., Jungbluth, N., Osses, M., Primas, A., 2007. Life Cycle Inventories of Chemicals. Ecoinvent Report №8. Swiss Centre for Life Cycle Inventories, Dübendorf, Switzerland.

AOO - Afval Overleg Orgaan, 2002a. Milieueffectrapport Landelijk Afvalbeheerplan 2001-2012. The Netherlands.

AOO - Afval Overleg Orgaan, 2002b. Milieueffectrapport Landelijk Afvalbeheerplan-Achtergronddocuemnt A5 Uitwerking afvalstroom "Batterijen (zinkbruinsteen \& alkaline)". The Netherlands.

APA, 2013a. Relatório de Estado do Ambiente 2013. APA-Agência Portuguesa do Ambiente (Portuguese Environment Agency). ISBN:978972-8577-67-4.

APA, 2013b. Relatório Anual 2012 Resíduos Urbanos. APA-Agência Portuguesa do Ambiente (Portuguese Environment Agency).

APA, 2014 a. Sistemas de Gestão e Infraestruturas. APA-Agência Portuguesa do Ambiente (Portuguese Environment Agency). $<$ http://www.apambiente.pt/ index.php?ref $=16 \&$ subref $=84 \&$ sub2ref $=933 \&$ sub3ref $=934>$.

APA, 2014b. Licenças ambientais emitidas, Gestão de Resíduos, Aterros de resíduos urbanos ou de outros resíduos não perigosos, com excepção dos aterros de resíduos inertes, que recebam mais 10 t por dia ou com uma capacidade total superior a 25000 t. APA-Agência Portuguesa do Ambiente (Portuguese Environment Agency). $<$ http://ladigital.apambiente.pt/>.

APA, 2014c. Licença Ambiental da Lipor (e aditamentos). Licenças ambientais emitidas, Gestão de Resíduos, Instalações de incineração de resíduos urbanos, abrangidas pelo Decreto -Lei n.o 85/2005, de 28 de Abril, com uma capacidade superior a $3 \mathrm{t}$ por hora. APA-Agência Portuguesa do Ambiente (Portuguese Environment Agency). $<$ http://ladigital.apambiente.pt/>.

APA, 2014d. Licença Ambiental da Valorsul (e aditamentos). Licenças ambientais emitidas, Gestão de Resíduos, Instalações de incineração de resíduos urbanos, abrangidas pelo Decreto -Lei n.o 85/2005, de 28 de Abril, 
com uma capacidade

superior a 3 t por hora. APA-Agência Portuguesa do Ambiente (Portuguese Environment Agency). <http://ladigital.apambiente.pt/>.

Bicocchi, S., 1998. Les polluants et les techniques d́ epuration des fumées (cas des unités de destruction thermique des déchets). Lavoisier TEC\&DOC, Paris.

Briffaerts, K., Spirinckx, C., Van der Linden, A., Vrancken, K., 2006. Integrale Evaluatie Van Verwerkingstechnieken Voor Belgische Afvalbatterijen (Zinkkool - en Alkalinefractie). Study by VITO Commissioned by OVAM (Flemish Waste Authority), Mol, Belgium.

Briffaerts, K., Spirinckx, C., Van der Linden, A., Vrancken, K., 2009. Waste battery treatment options: comparing their environmental performance. Waste Manage. 29, 2321-2331.

Classen, M., Althaus, H-J., Blaser, S., Tuchschmid, M., Jungbluth, N., Doka, G., Faist Emmenegger, M., Scharnhorst, W., 2009. Life cycle inventories of metals. Ecoinvent Report N 10. Swiss Centre for Life Cycle Inventories, Dübendorf, Switzerland.

Commission of the European Communities, 2003. Commission Staff Working Paper, Directive of the European Parliament and of the Council on Batteries and Accumulators and Spent Batteries and Accumulators, Extended Impact Assessment. COM(2003)723 final. $<$ http://ec.europa.eu/environment/ waste/batteries/pdf/exten_impact_assessment.pdf $>$.

Doka, G., 2009. Life Cycle Inventories of Waste Treatment Services. Ecoinvent Report №13. Swiss Centre for Life Cycle Inventories, Dübendorf, Switzerland.

Doka, G., 2013. Updates to Life Cycle Inventories of Waste Treatment Services - Part II: Waste Incineration. Doka Life Cycle Assessments, Zurich. $<$ http://www.doka. ch/ecoinventMSWIupdateLCI2013.pdf $>$.

Ecoinvent, 2010. Ecoinvent Database v2.2. Swiss Centre for Life Cycle Inventories. Duebendorf. Switzerland.

EEA, 2009. EMEP/EEA Air Pollutant Emission Inventory Guidebook-2009: Municipal Waste Incineration, EEA - European Environment Agency. $<$ http:// www.eea.europa.eu/publications/emep-eea-emission-inventoryguidebook- 2009>.

Erichsen, H., Hauschild, M., 2000. Technical Data for Waste Incineration Background for Modelling of Product Specific Emissions in a Life Cycle Assessment Context. Department of Manufacturing Engineering Technical University of Denmark.

ERM - Environmental Resources Management, 2006. Battery Waste Management Life Cycle Assessment, study on behalf of DEFRA, Final Report.

European Commission, 2009. Study on the Calculation of Recycling Efficiencies and Implementation of Export Article (Art. 15) of the Batteries 
Directive 2006/66/EC, Final Report.

Faist Emmenegger, M., Heck, T., Jungbluth, N., Tuchschmid, M., 2007. Erdgas. In: Sachbilanzen von Energiesystemen: Grundlagen für den ökologischen Vergleich von Enegiesystemen und den Einbezug von Energiesystemen in Ökobilanzen für die Schweiz. Ecoinvent Report №6-V. Swiss Centre for Life Cycle Inventories, Dübendorf, Switzerland.

Frischknecht, R., Tuchschmid, M., Faist Emmenegger, M., Bauer, C., Dones, R., 2007. Strommix und Stromnetz. In: Sachbilanzen von Energiesystemen: Grundlagen für den ökologischen Vergleich von Enegiesystemen und den Einbezug von Energiesystemen in Ökobilanzen für die Schweiz. Ecoinvent Report №6-XVI. Swiss Centre for Life Cycle Inventories, Dübendorf, Switzerland.

Goedkoop, M.J., Heijungs, R., Huijbregts, M., De Schryver, A., Struijs, J., Van Zelm, R., 2013. ReCiPe 2008, A Life Cycle Impact Assessment Method Which Comprises Harmonised Category Indicators at the Midpoint and the Endpoint Level. First edition Report I: Characterisation. <http://www.lcia-recipe.net>.

ISO - International Organization for Standardization, 2006a. ISO 14040:2006,

Environmental Management - Life Cycle Assessment - Principles and Framework. Geneva, Switzerland.

ISO - International Organization for Standardization, 2006b. ISO 14044:2006, Environmental Management - Life Cycle Assessment - Requirements and guidelines. Geneva, Switzerland.

Jungbluth, N., 2007. Erdöl. In: Sachbilanzen von Energiesystemen: Grundlagen für den ökologischen Vergleich von Enegiesystemen und den Einbezug von Energiesystemen in Ökobilanzen für die Schweiz. Ecoinvent Report №6-IV. Swiss Centre for Life Cycle Inventories, Dübendorf, Switzerland.

Kellenberger, D., Althaus, H.-J., Jungbluth, N., Künniger, T., Lehmann, M., Thalmann, P., 2007. Life Cycle Inventories of Building Products. Ecoinvent Report №7. Swiss Centre for Life Cycle Inventories, Dübendorf, Switzerland.

Koehler, A., Peyer, F., Salzmann, C., Saner, D., 2011. Probabilistic and technology- specific modeling of emissions from municipal solid-waste incineration. Environ. Sci. Technol. 45 (8), 3487-3495. http://dx.doi.org/10.1021/es1021763.

Lipor, 2013. Relatório de Sustentabilidade 2012. <http://www.lipor.pt/pt/ bibliotecas/>.

Official Journal of the European Union, 2006. Directive 2006/66/EC of the European Parliament and of the Council of 6 September 2006 on batteries and accumulators and waste batteries and accumulators and repealing Directive 91/157/EEC. Off. J. L 266 (26/09/2006).

Official Journal of the European Union, 2008. Directive 2008/98/EC of the European Parliament and of the Council of 19 November 2008 on waste 
and repealing certain Directives. Off. J. L 312 (22/11/2008).

Spielmann, M., Bauer, C., Dones, R., Tuchschmid, M., 2007. Transport Services.

Ecoinvent Report №14. Swiss Centre for Life Cycle Inventories, Dübendorf, Switzerland.

Valorsul, 2009. Relatório de Sustentabilidade 2009. $<$ http://www.valorsul.pt/media/ 85979/rs_valorsul_2009.pdf > .

Valorsul, 2013. Relatório e Contas 2012 \& Caderno de Sustentabilidade. $<$ http:// Www.valorsul.pt/media/222437/relatorio-e-contas-2012valorsul_v2.pdf $>$.

Werner, F., Althaus, H.-J., Künniger, T., Richter, K., Jungbluth, N., 2007. Life Cycle Inventories of Wood as Fuel and Construction Material. Ecoinvent Report №9. Swiss Centre for Life Cycle Inventories, Dübendorf, Switzerland.

Xará, S., Delgado, J., Almeida, M.F., Costa, C., 2009. Laboratory study on the leaching potential of spent alkaline batteries. Waste Manage. 29 (7), 21212131. http:// dx.doi.org/10.1016/j.wasman.2009.03.010.

Xará, S., Delgado, J., Almeida, M.F., Costa, C., 2013. Laboratory study on the leaching potential of spent alkaline batteries using a MSW landfill leachate. J. Mater. Cycles 15 (1), 61-72. http://dx.doi.org/10.1007/s10163-012-00918.

Xará, S., Almeida, M.F., Costa, C., 2014. Life cycle assessment of alternatives for recycling abroad alkaline batteries from Portugal. Int. J. Life Cycle Assess. 19 (7), 1382-1408. http://dx.doi.org/10.1007/s11367-014-0746-x. 
Environment
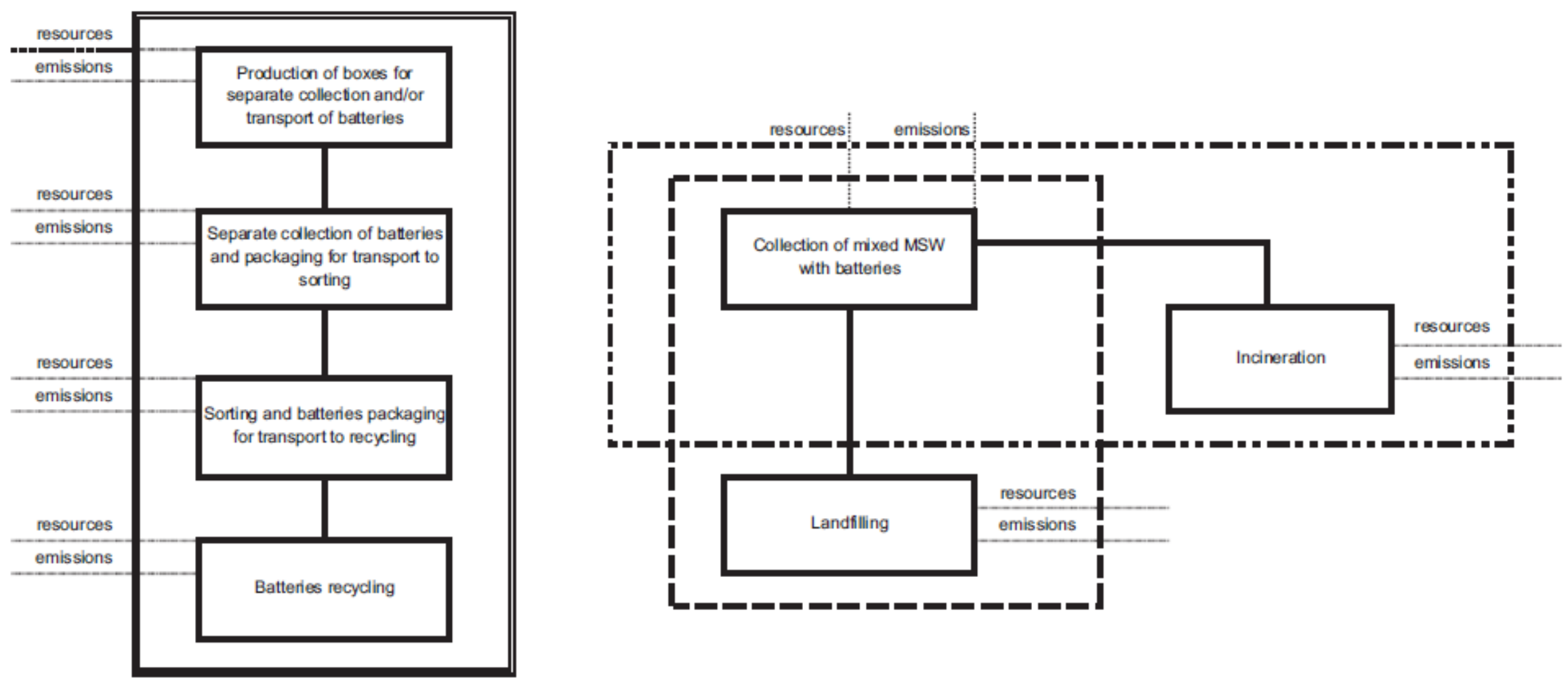

$$
\begin{aligned}
& \ldots-\ldots \text { System 1: Landfilling } \\
& \ldots-\ldots-\cdots-\text { System 2: Incineration } \\
& \hline \hline
\end{aligned}
$$

Fig. 1. Simplified Schematic representation of the three systems under study. 
Inputs
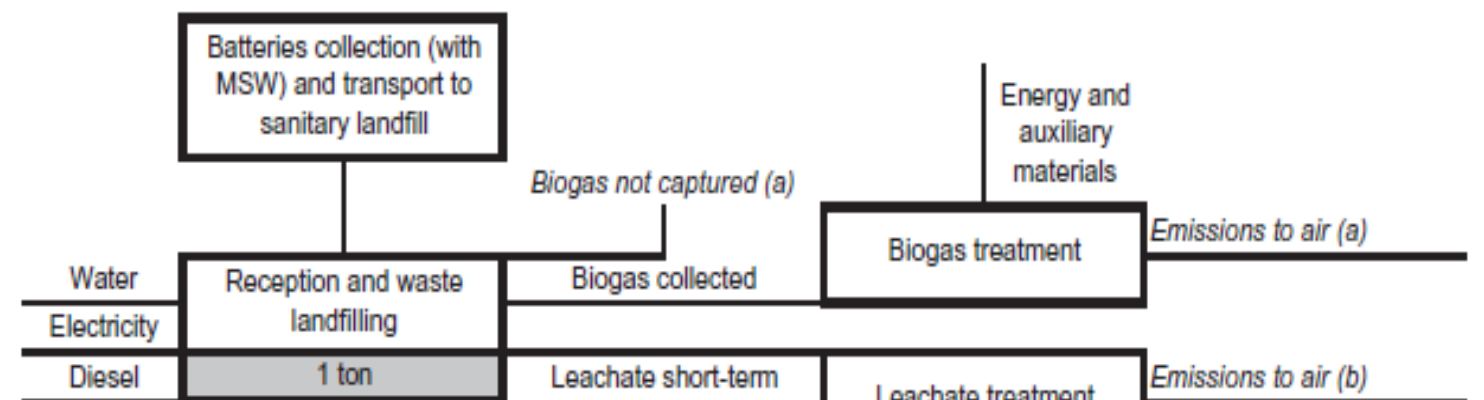

\begin{tabular}{|c|c|c|c|c|}
\hline Diesel & 1 ton & \multirow[t]{3}{*}{ Leachate short-term } & \multirow{2}{*}{ Leachate treatment } & Emissions to air (b) \\
\hline & & & & Emissions to water (b) \\
\hline & Leachate long-term (c) & & $\begin{array}{c}\text { Energy and } \\
\text { auxiliary } \\
\text { materials }\end{array}$ & Sludge \\
\hline
\end{tabular}

outputs categories

(a) Burden from direct release or incineration of landfill biogas

(b) Emissions from short-term leachate treatment and idem and incineration of resulting sludge

(c) Emissions from long-term leac hate ( $>100$ years) directly from MSW landfill and indirectly via incineration of sludge from leachate treatement

Incineration of sludge 1

Bottom and fly ashes 1

Bottom and fly ah landfill

(20)

Leachate long-term (c)

Fig. 2. Boundaries of system 1, landfilling. 


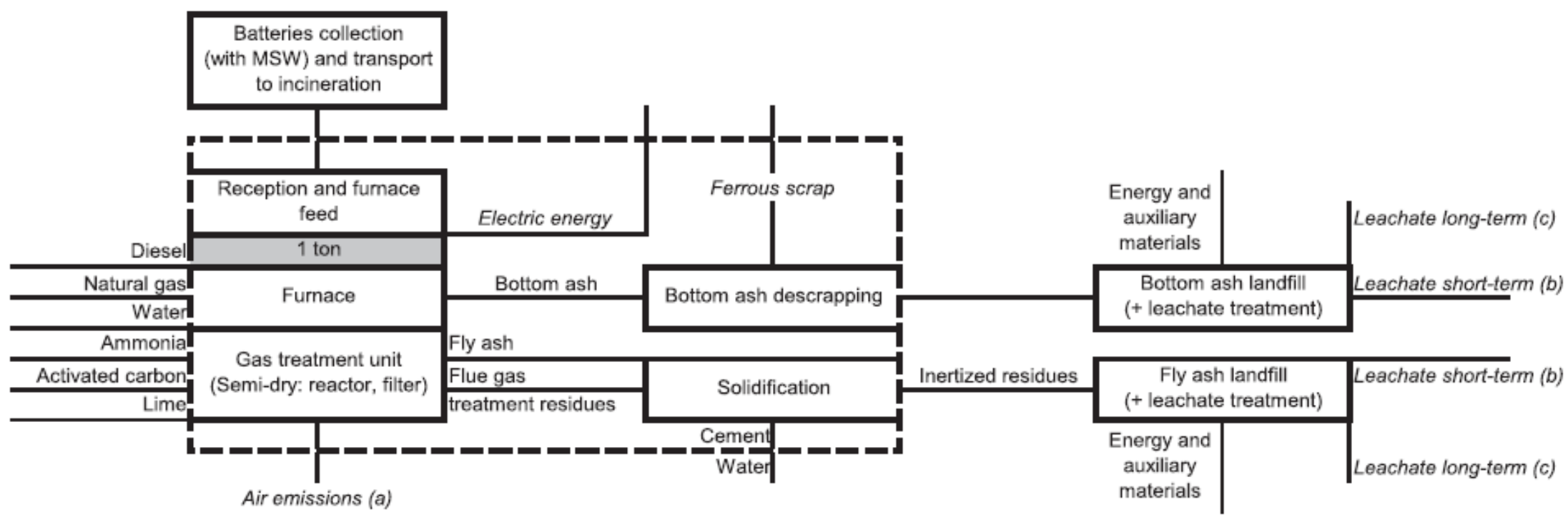

Legend: :

Outputs

outputs categories:
(a) Burden from incineration
(b) Short-term emissions from leachate treatment of bottom ash and fly ash landfill
(c) Long-term emissions (>100years) from bottom ash and fly ash landfill

Fig. 3. Boundaries of system 2, incineration. 


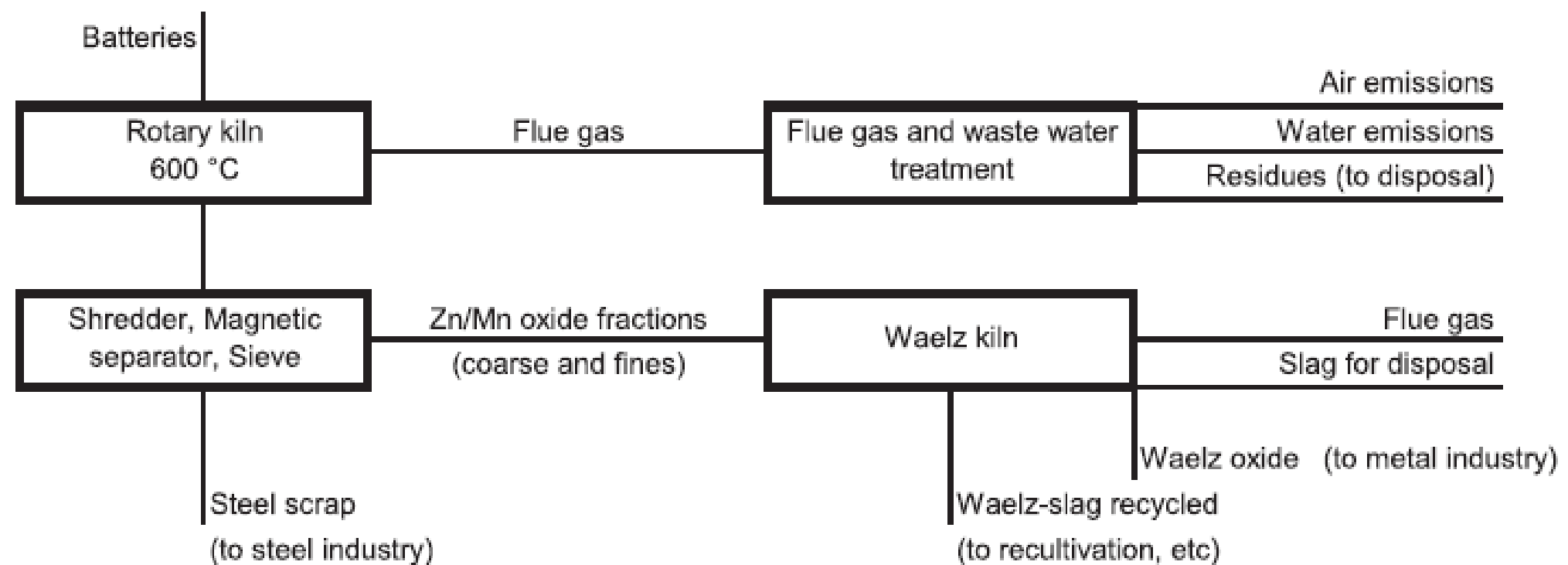

Fig. 4. Schematic representation of the batteries recycling process (Xará et al., 2014) 

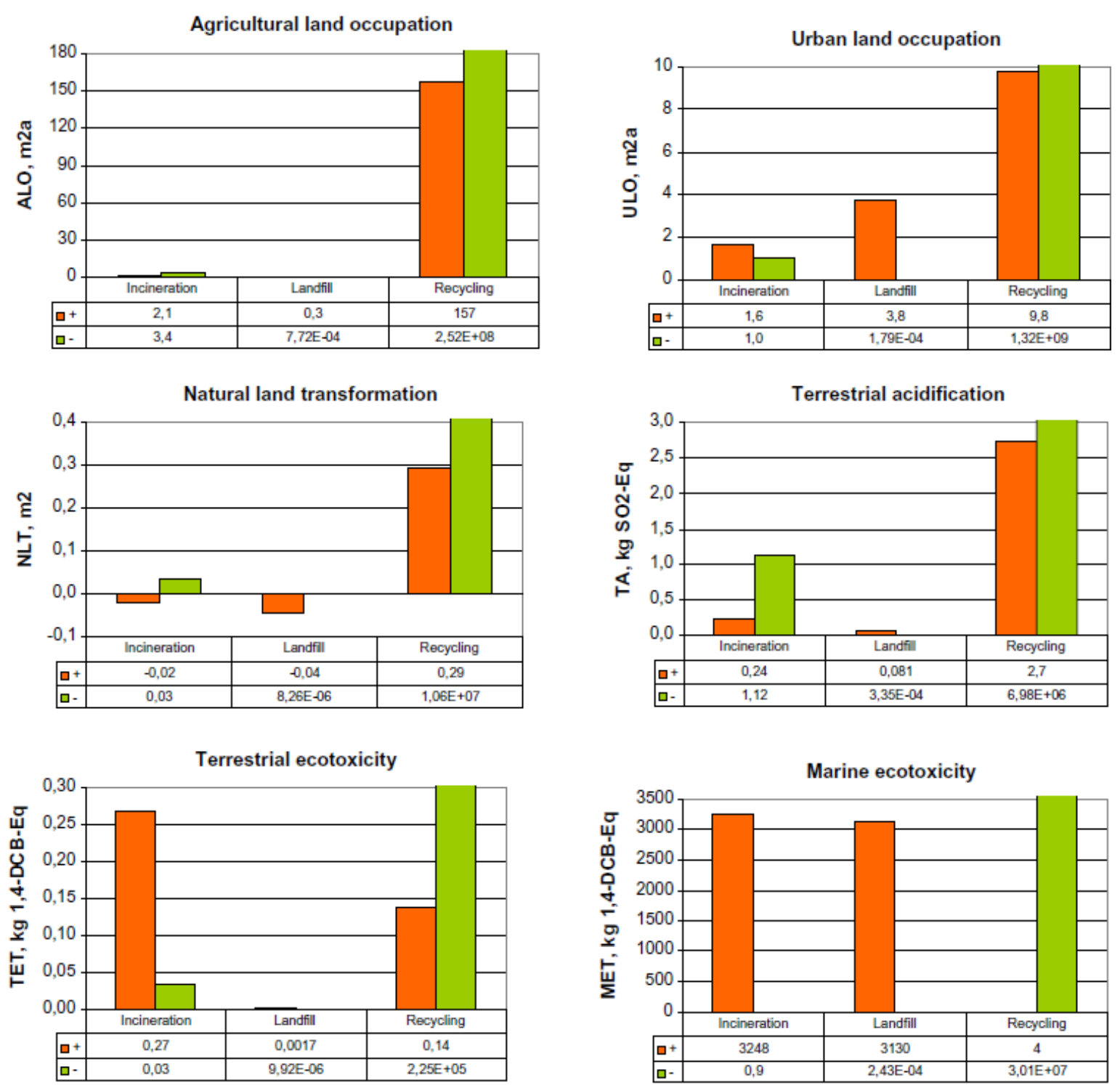

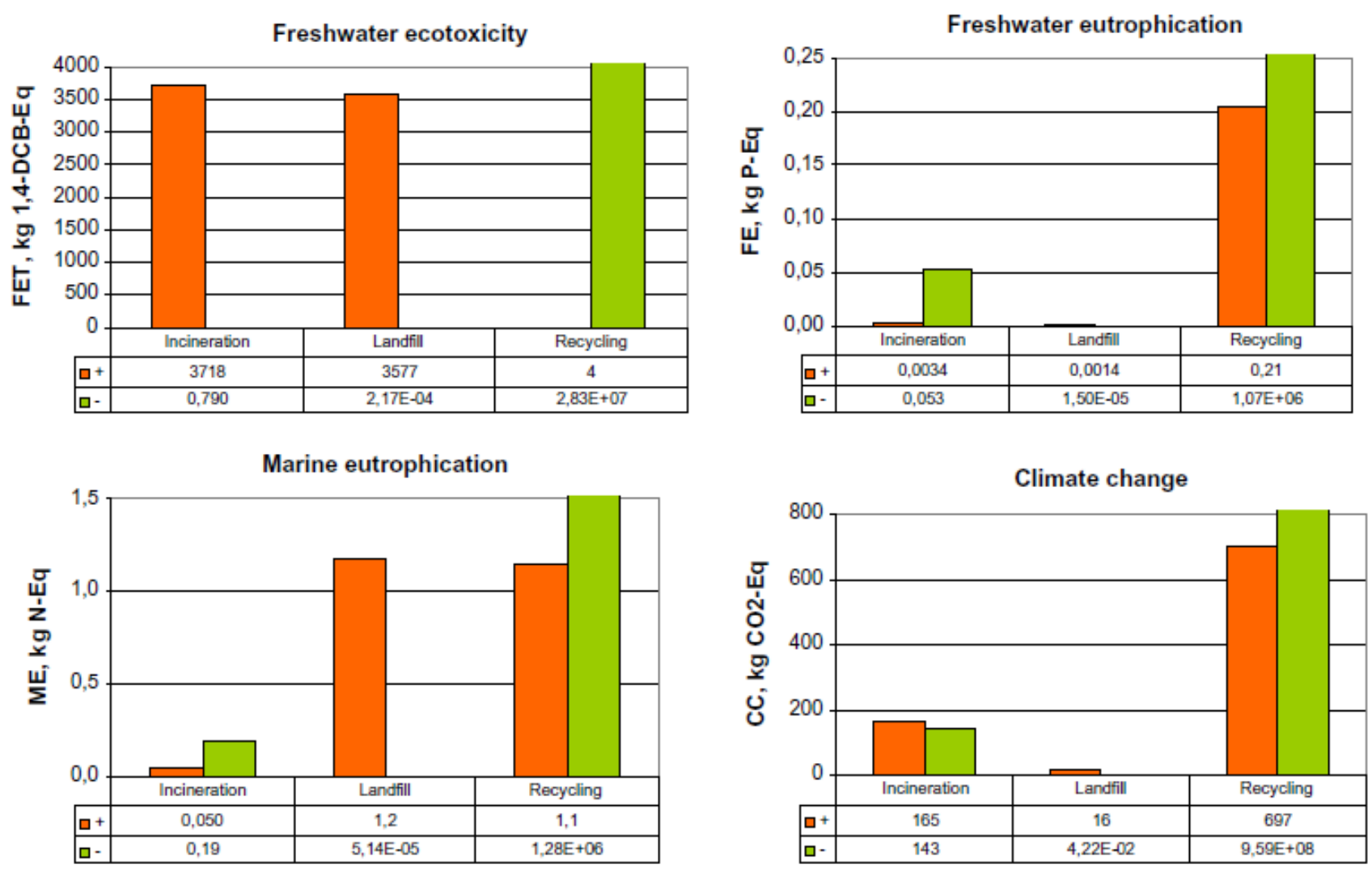

Fig. 5. Impact assessment results for the impact categories that belong to the protection area of Ecosystem. (For interpretation of color in this figure, the reader is referred to the web version of this article.) 

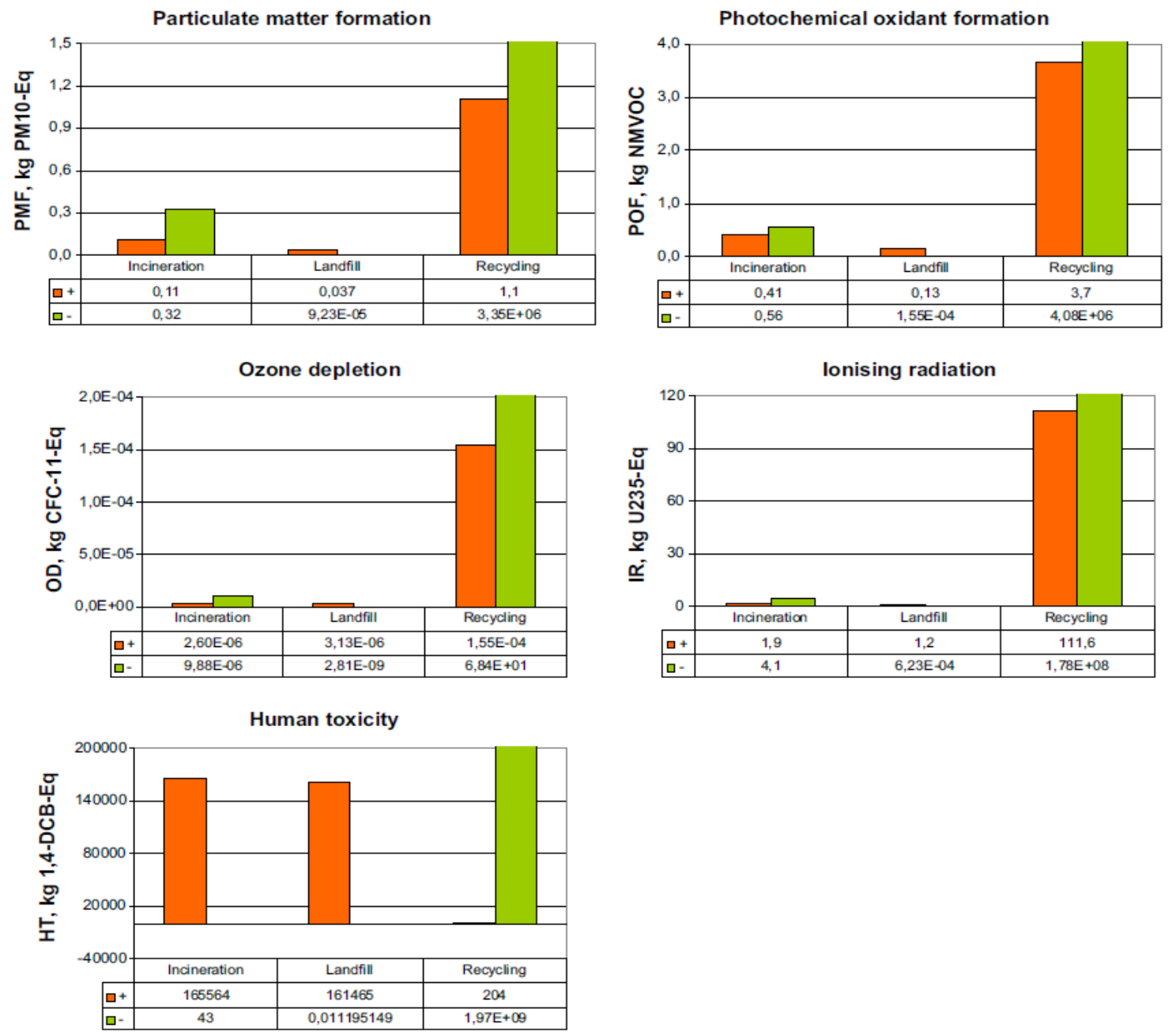

Fig. 6. Impact assessment results for the impact categories that belong to the protection area of Human health. (For interpretation of color in this figure, the reader is referred to the web version of this article.) 

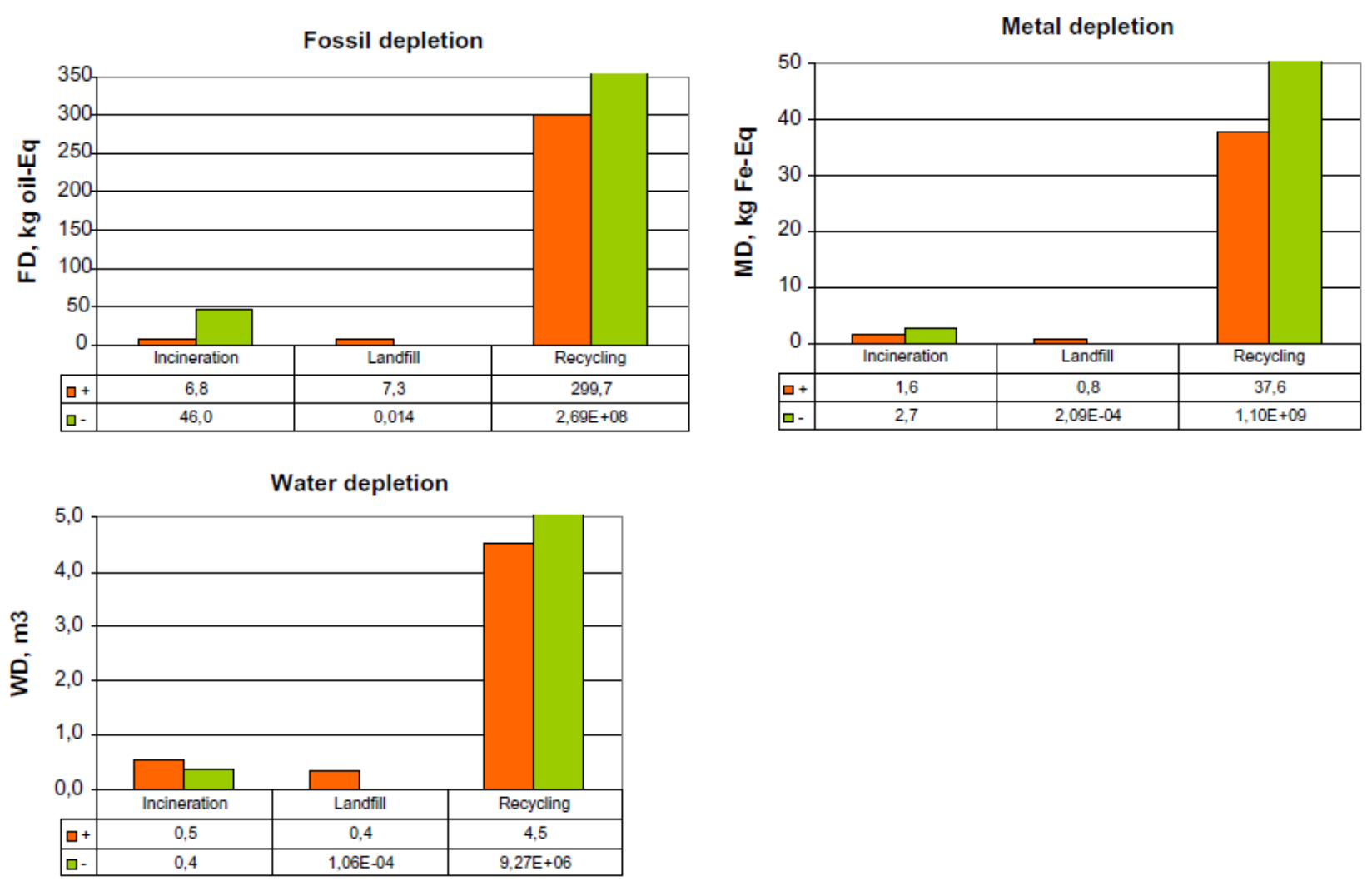

Fig. 7. Impact assessment results for the impact categories that belong to the protection area of Resources. (For interpretation of color in this figure, the reader is referred to the web version of this article.) 


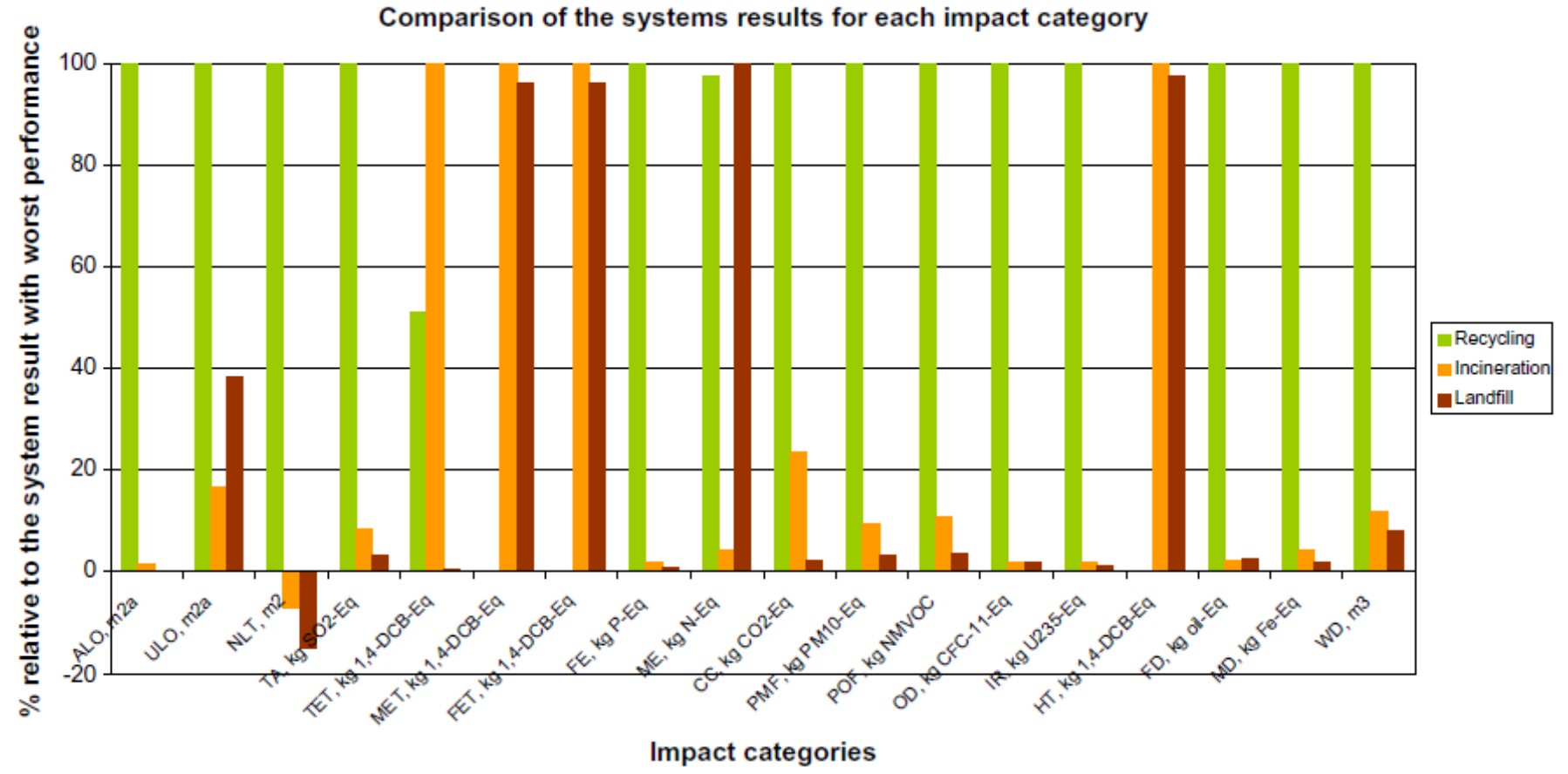

Fig. 8. Comparison of the systems results for each impact category without considering the energy and materials recovery. 


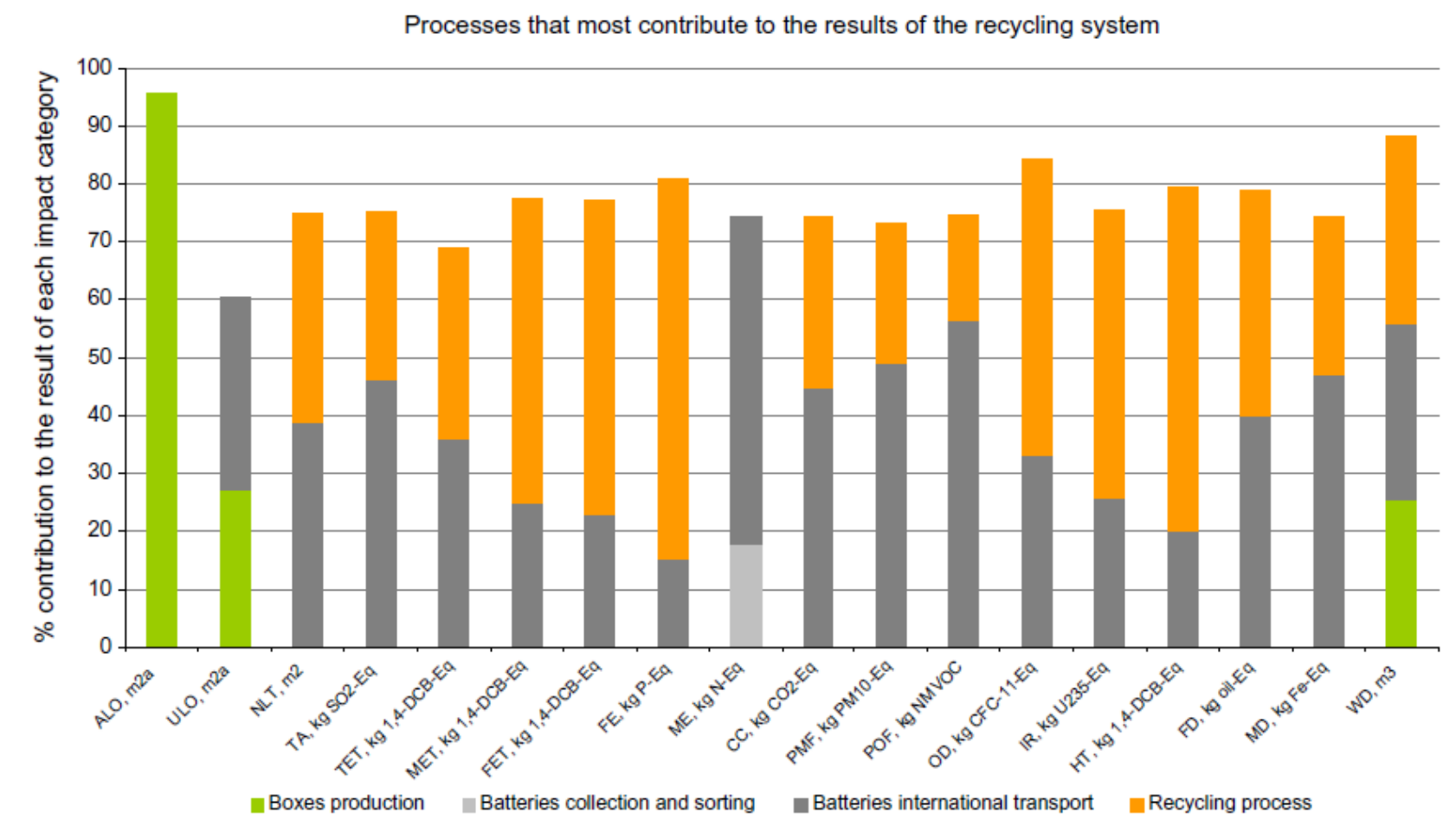

Fig. 9. Main processes contribution to results on recycling system for each impact category (only one process is included if its contribution is higher than $70 \%$, two processes in the other cases or three if 2 nd and 3rd contributors are of similar magnitude). 


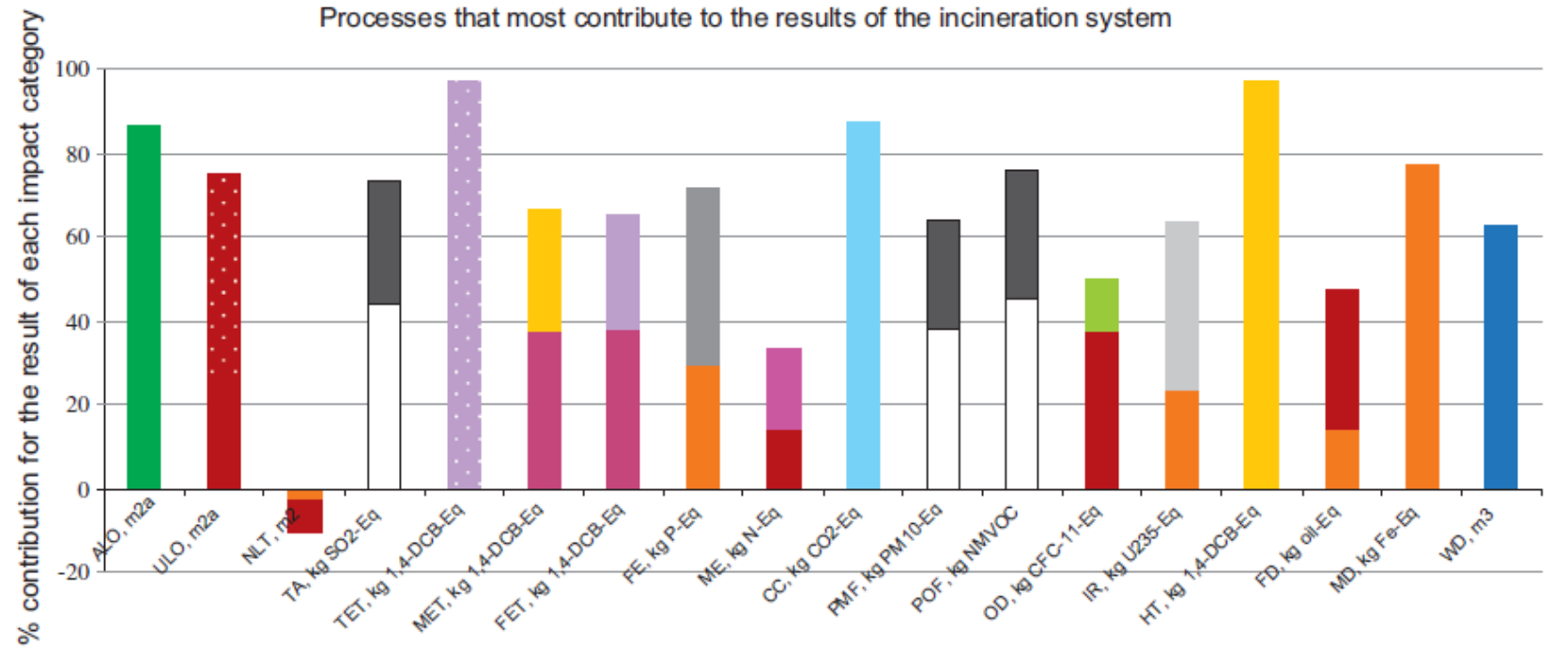

\begin{tabular}{|c|c|c|}
\hline Municipal waste incineration plant & -Slag compartment & - Process-specific burdens, slag compartment \\
\hline -Charcoal & 口Thermal NOx, air & - Fuel NOx, air \\
\hline =Zinc, air & aCopper, ground_It & Manganese, ground_It \\
\hline Zinc ground_It & Disposal of cement, to residual material landfill & Nitrate, ground_It \\
\hline $\mathrm{CO} 2$ fossil, ar & Natural gas & - Cement \\
\hline
\end{tabular}

Fig. 10. Main processes contribution to results on incineration system for each impact category (only one process is included if its contribution is higher than $70 \%$ and two processes in the other cases). 
Processes that most contribute to the results of the landfill system

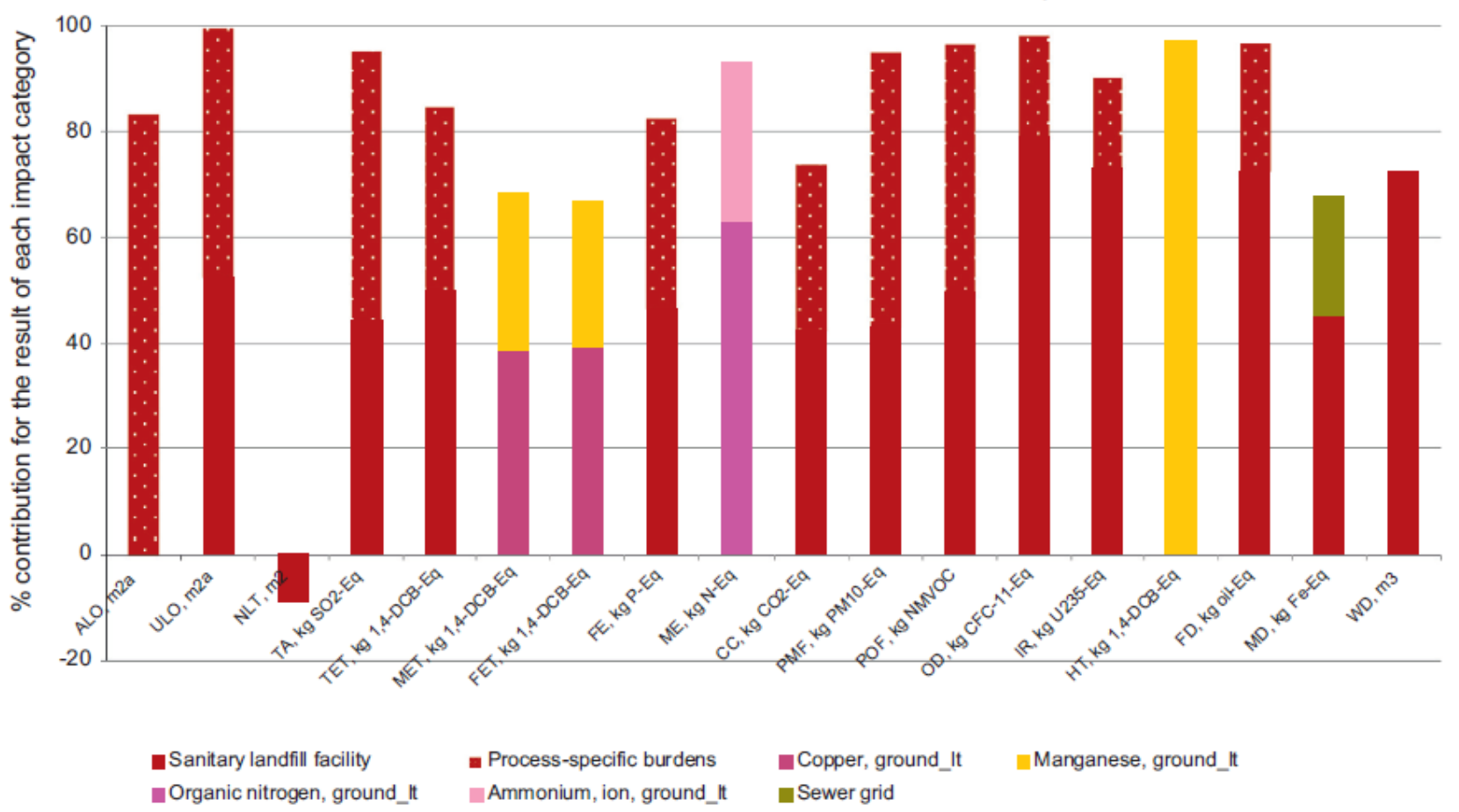

Fig. 11. Main processes contribution to results on landfill system for each impact category (only one process is included if its contribution is higher than $70 \%$ and two processes in the other cases). 

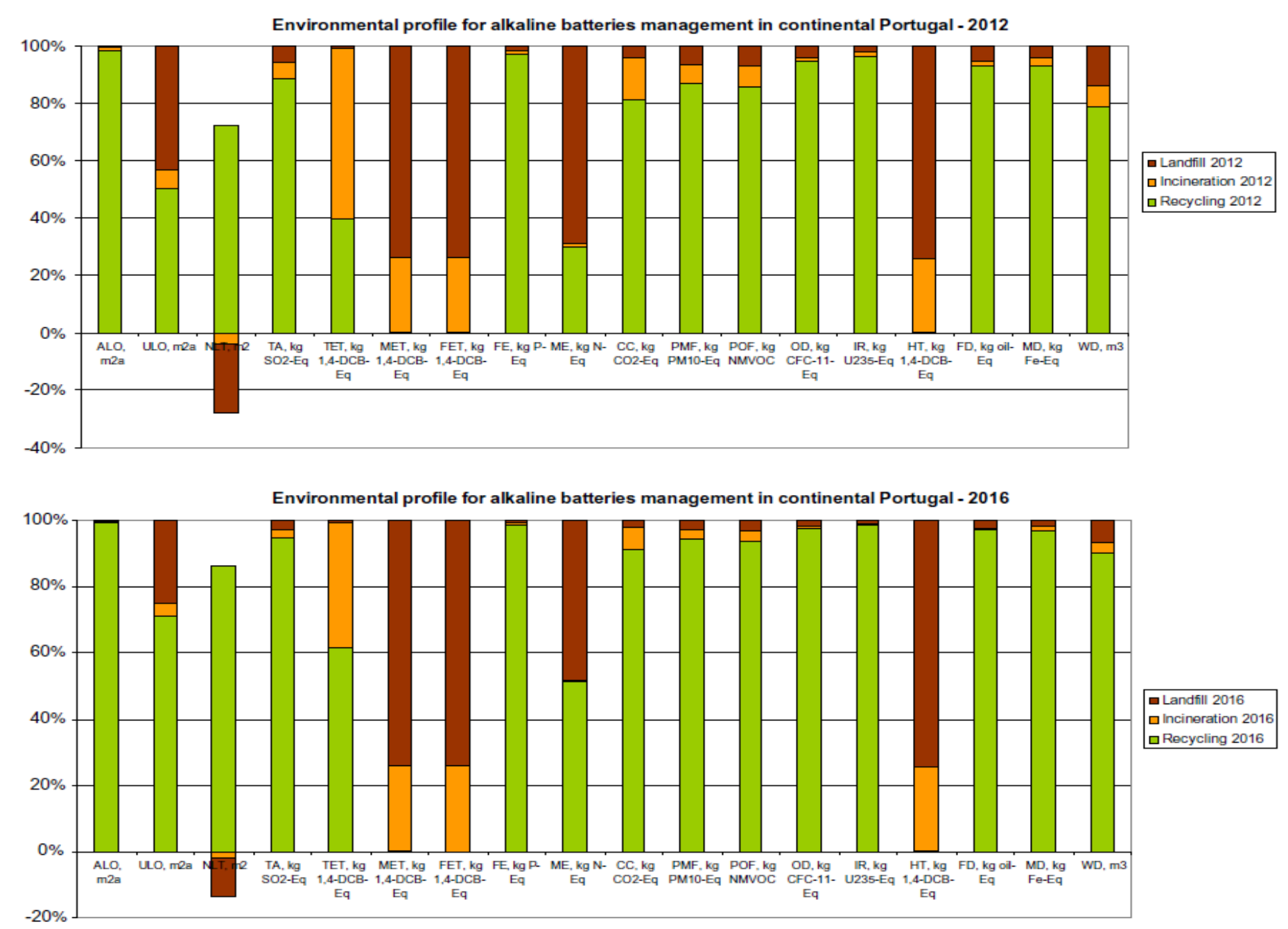

Fig. 12. Scenarios for alkaline batteries management in continental Portugal, 2012 and 2016

Table 1

Characteristics of the sanitary landfills in operation in continental Portugal in 2012 and some parameters of the landfill model (from Doka (2009)). The values considered in the present study are indicated in bold (see Section 3.2). 


\begin{tabular}{|c|c|c|}
\hline & Sanitary landfills in continental Portugal & $\begin{array}{l}\text { Parameters of the model (from Doka } \\
(2009) \text { ) }\end{array}$ \\
\hline Landfill volume $\left(\mathrm{m}^{3}\right)$ & $1,601,468$ Note 1 & $1,800,000$ \\
\hline Landfill capacity (ton) & $1,662,487$ Note 1 & $1,800,000$ \\
\hline $\begin{array}{l}\text { Water consumption } \\
\text { (1/ton waste) }\end{array}$ & From 5.5 to 230 , mean $=\mathbf{6 9}$ Note 2 & Not considered \\
\hline $\begin{array}{l}\text { Electricity } \\
\text { consumption } \\
\text { (kW h/ton waste) }\end{array}$ & From 1.1 to 12 , mean $=4.7$ Note 3 & 1.365 \\
\hline $\begin{array}{l}\text { Diesel consumption } \\
\quad(1 / \text { ton waste })\end{array}$ & From 0.58 to 15 , mean $=2.9$ Note 4 & 1.3 \\
\hline \multirow[t]{4}{*}{ Landfill gas treatment } & Only for 3 landfills ( $5 \%$ of the total capacity) gas collection was not referred & $47 \%$ emitted directly \\
\hline & $\begin{array}{l}60 \% \text { of the total landfill capacity ( } 9 \text { landfills) had or foresaw landfill gas recovery (electricity). } \\
\text { All the others (35\%) had or foresaw open flare without energy recovery. Note } 5\end{array}$ & 53\% captured: \\
\hline & Assuming a collection efficiency of $40 \%$ : & $\begin{array}{l}-66 \% \text { recovered (electricity and heat, } \\
\text { efficiency of } 27.8 \text { and } 13.5 \text { respectively) }\end{array}$ \\
\hline & $\begin{array}{l}-38 \% \text { of the total produced landfill gas is collected; } 62 \% \text { is directly emitted } \\
-66.7 \% \text { of the collected gas is recovered and } 33.3 \% \text { is open flared }\end{array}$ & - $34 \%$ open flare without energy recovery \\
\hline \multirow[t]{3}{*}{ Leachate treatment } & Leachate production is not available & Leachate production: $0.025 \mathrm{l} / \mathrm{a}$ \\
\hline & $\begin{array}{l}\text { All the landfills have local treatment or local pretreatment previous to municipal wastewater } \\
\text { treatment }\end{array}$ & $\begin{array}{l}\text { Municipal wastewater treatment } \\
\text { plant + incineration of sludge }\end{array}$ \\
\hline & Resulting sludges are landfilled & \\
\hline
\end{tabular}

Table 2. Impact categories and respective abbreviation, units and area of protection addressed at the midpoint level ReCiPE 2014. 


\begin{tabular}{|c|c|c|c|}
\hline Impact category name & Abbreviation & Unit & Area of protection \\
\hline Ozone depletion & OD & kg CFC-11 eq & Human health \\
\hline Human toxicity & HT & $\mathrm{kg} 1,4-\mathrm{DB}$ eq & Human health \\
\hline Ionizing radiation & IR & $\mathrm{kg} \mathrm{U}_{235} \mathrm{eq}$ & Human health \\
\hline Photochemical oxidant formation & POF & kg NMVOC & Human health \\
\hline Particulate matter formation & PMF & $\mathrm{kg}$ PM10 eq & Human health \\
\hline Climate change & $\mathrm{CC}$ & $\mathrm{kg} \mathrm{CO}_{2}$ eq & Ecosystem ${ }^{*}$ \\
\hline Terrestrial ecotoxicity & TET & kg 1,4-DB eq & Ecosystem \\
\hline Terrestrial acidification & TA & $\mathrm{kg} \mathrm{SO}_{2} \mathrm{eq}$ & Ecosystem \\
\hline Agricultural land occupation & ALO & $\mathrm{m}^{2} \times \mathrm{yr}$ & Ecosystem \\
\hline Urban land occupation & ULO & $\mathrm{m}^{2} \times \mathrm{yr}$ & Ecosystem \\
\hline Natural land transformation & NLT & $\mathrm{m}^{2}$ & Ecosystem \\
\hline Marine ecotoxicity & MET & kg 1,4-DB eq & Ecosystem \\
\hline Marine eutrophication & ME & $\mathrm{kg} \mathrm{N} \mathrm{eq}$ & Ecosystem ${ }^{*}$ \\
\hline Freshwater eutrophication & FE & $\mathrm{kg}$ P eq & Ecosystem \\
\hline Freshwater ecotoxicity & FET & kg 1,4-DB eq & Ecosystem \\
\hline Fossil resource depletion & $\mathrm{FD}$ & $\mathrm{kg}$ oil & Resources \\
\hline Mineral resource depletion & MD & $\mathrm{kg} \mathrm{Fe} \mathrm{eq}$ & Resources \\
\hline Water depletion & WD & $\mathrm{m}^{3}$ & Resources ${ }^{*}$ \\
\hline
\end{tabular}

- ReCiPe connects by modeling the midpoint categories until endpoint categories (not used here) that are associated to the areas of protection indicated in this table. This connection is not quantitatively established for ME and WD and for CC the connection is to Ecosystem \& Human Health protection areas. To simplify but because it is intended to use the designation of Area of protection, for these impact categories it is considered as Ecosystem.

Table 3 Characterization of batteries considered in the present study. 


\begin{tabular}{|c|c|c|c|c|c|c|c|c|c|}
\hline Bat tery components & & & $\begin{array}{l}\text { Anode cap + metal } \\
\text { separator + cat hode } \\
\text { collector }\end{array}$ & $\begin{array}{l}\text { Anode } \\
\text { collector }\end{array}$ & $\begin{array}{l}\text { Plastic } \\
\text { grommet }\end{array}$ & $\begin{array}{l}\text { Plastic } \\
\text { sleeve }\end{array}$ & $\begin{array}{l}\text { Insulator+ } \\
\text { separator }\end{array}$ & Cathode & Anode \\
\hline Base materials & & & Steel & $\begin{array}{l}\text { Tin-plated } \\
\text { brass }\end{array}$ & PA & PUC & Paper & $\begin{array}{l}\mathrm{MnO}_{2} \mathrm{C} \\
\mathrm{KOH}\end{array}$ & $\begin{array}{l}\mathrm{Zn}, \mathrm{ZnO} \\
\mathrm{KOH}\end{array}$ \\
\hline Inert or burnable & & & Inert & Inert & Burmable & Burnable & Bumable & Burnable & Bumable \\
\hline Amount per battery ( $\mathrm{g} /$ battery) (1) & & & 4.68 & 0.438 & 0.218 & 0.237 & 0.225 & & \\
\hline Fraction in waste (kg/kg battery) & & & 020 & 0.02 & 0.01 & 0.01 & 0.01 & 0.55 & 0.21 \\
\hline Upper heating value (1) & Ho & $\mathrm{MJ} / \mathrm{kg}$ & oo & 0.0 & 34.5 & 20.0 & 23.2 & 6.28 & 4.88 \\
\hline $\begin{array}{l}\text { Lower heating value (1) } \\
\text { Water content ( } 1 \text { ) }\end{array}$ & $\begin{array}{l}\mathrm{Hu}_{2} \\
\mathrm{H}_{2} \mathrm{O}\end{array}$ & $\begin{array}{l}\mathrm{Mj} / \mathrm{kg} \\
\mathrm{kg} / \mathrm{kg} \\
\text { waste }\end{array}$ & oo & 0.0 & $\begin{array}{l}32.6 \\
1.4 \mathrm{E}-02\end{array}$ & $\begin{array}{l}19.1 \\
1.7 \mathrm{E}-02\end{array}$ & $\begin{array}{l}22.1 \\
5.9 E-02\end{array}$ & $\begin{array}{l}6.28 \\
7.7 E-02\end{array}$ & $\begin{array}{l}4.88 \\
2.1 \mathrm{E}-01\end{array}$ \\
\hline Oxygen & $\mathbf{0}$ & $\begin{array}{l}\mathrm{kg} / \mathrm{kg} \\
\text { waste }\end{array}$ & & & $1.4 \mathrm{E}-01(4)$ & & 4.5E-01 (4) & $4.2 \mathrm{E}-01$ (3) & $7.8 E-02(3)$ \\
\hline Hydrogen & $\mathbf{H}$ & $\begin{array}{l}\mathrm{kg} / \mathrm{kg} \\
\text { waste }\end{array}$ & & & $9.6 \mathrm{E}-02(4)$ & 4.7E-02 (4) & 5.7E- 02 (4) & & \\
\hline Carbon & c & $\begin{array}{l}\mathrm{kg} / \mathrm{kg} \\
\text { waste }\end{array}$ & $1.0 E-03(2)$ & & $6.3 \mathrm{E}-01(4)$ & $3.8 \mathrm{E}-01(4)$ & 4. $1 \mathrm{E}-01$ (4) & $5.5 E-02(5)$ & $0.0 \mathrm{E}+00(5)$ \\
\hline Sulfur & s & $\begin{array}{l}\mathrm{kg} / \mathrm{kg} \\
\text { waste }\end{array}$ & & & & & & $1.1 \mathrm{E}-03(5)$ & $27 \mathrm{E}-05(5)$ \\
\hline Nitrogen & $\mathrm{N}$ & $\begin{array}{l}\mathrm{kg} / \mathrm{kg} \\
\text { waste }\end{array}$ & & & $1.2 \mathrm{E}-01(4)$ & & & & \\
\hline Chlorine & a & $\begin{array}{l}\mathrm{kg} / \mathrm{kg} \\
\text { waste }\end{array}$ & & & & $5.6 \mathrm{E}-01(4)$ & & $9.2 \mathrm{E}-06(5)$ & $5.6 \mathrm{E}-05(5)$ \\
\hline Arsenic (6) & As & $\begin{array}{l}\mathrm{kg} / \mathrm{kg} \\
\text { waste }\end{array}$ & $4.3 \mathrm{E}-06$ & $0.0 E+\infty O$ & $0.0 E+00$ & $0.0 \mathrm{E}+\infty 0$ & $0.0 E+\infty O$ & $7.5 \mathrm{E}-08$ & 5,7E- 08 \\
\hline Cadmium (6) & cd & $\begin{array}{l}\mathrm{kg} / \mathrm{kg} \\
\text { waste }\end{array}$ & $1.3 \mathrm{E}-0.05$ & $0.0 E+\infty 0$ & $0.0 E+\infty 0$ & $0.0 E+\infty O$ & $0.0 \mathrm{E}+\infty 0$ & $0.0 E+\infty$ & $0.0 \mathrm{E}+00$ \\
\hline Cobalt (6) & co & $\begin{array}{l}\mathrm{kg} / \mathrm{kg} \\
\text { waste }\end{array}$ & $1.1 \mathrm{E}-04$ & $0.0 E+\infty 0$ & $0.0 E+00$ & $0.0 E+00$ & $0.0 E+00$ & $2.6 E-05$ & $0.0 \mathrm{E}+00$ \\
\hline Chromium (6) & $\mathrm{Cr}$ & $\begin{array}{l}\mathrm{kg} / \mathrm{kg} \\
\text { waste }\end{array}$ & $20 \mathrm{E}-03$ & 1.7E-0.5 & $3.2 \mathrm{E}-05$ & $2.4 \mathrm{E}-04$ & $1.8 \mathrm{E}-04$ & $7.4 \mathrm{E}-06$ & $0.0 E+00$ \\
\hline Copper (6) & $\mathrm{Cu}$ & $\begin{array}{l}\mathrm{kg} / \mathrm{kg} \\
\text { waste }\end{array}$ & $9.2 \mathrm{E}-05$ & $6.4 \mathrm{E}-01$ & $0.0 E+00$ & $4.5 \mathrm{E}-0.5$ & $0.0 E+00$ & $0.0 \mathrm{E}+\infty$ & $0.0 E+00$ \\
\hline Mercury (6) & $\mathrm{Hg}$ & $\begin{array}{l}\mathrm{kg} / \mathrm{kg} \\
\text { waste }\end{array}$ & $Q Q E+O D$ & $0.0 E+00$ & $0.0 E+00$ & $0.0 E+00$ & $0.0 E+00$ & $2.9 E-07$ & $0.0 E+00$ \\
\hline Manganese (6) & Mn & $\begin{array}{l}\mathrm{kg} / \mathrm{kg} \\
\text { waste }\end{array}$ & $2.2 \mathrm{E}-03$ & $0.0 E+00$ & $2.0 E-04$ & 5.7E-0. & 9.5E-04 & $4.2 \mathrm{E}-01$ & 1.4E-05 \\
\hline Nickel (6) & $\mathrm{Ni}$ & $\mathrm{kg} / \mathrm{kg}$ & $1.4 \mathrm{E}-02$ & $3.5 E-0.5$ & 4.6E-0. & $1.2 \mathrm{E}-04$ & $1.2 \mathrm{E}-04$ & $2.2 \mathrm{E}-0.5$ & $0.0 \mathrm{E}+00$ \\
\hline Lead (6) & $\mathrm{Pb}$ & $\begin{array}{l}\mathrm{kg} / \mathrm{kg} \\
\text { waste }\end{array}$ & 1.OE-04 & $5.5 E-0.5$ & 8.6E -05 & $1.1 \mathrm{E}-04$ & $3.5 \mathrm{E}-04$ & $3.1 \mathrm{E}-0.5$ & $3.6 \mathrm{E}-0.5$ \\
\hline Antimony (6) & sb & $\begin{array}{l}\mathrm{kg} / \mathrm{kg} \\
\text { waste }\end{array}$ & 9.4E-0.5 & $0.0 E+00$ & $0.0 \mathrm{E}+00$ & $0.0 E+00$ & $0.0 \mathrm{E}+00$ & $0.0 \mathrm{E}+\infty$ & D. $0 E+00$ \\
\hline Tin & Sn & $\begin{array}{l}\mathrm{kg} / \mathrm{kg} \\
\text { waste }\end{array}$ & & $5.5 E-03$ (3) & & & & & \\
\hline Vanadiu $m(6)$ & $\mathrm{v}$ & $\begin{array}{l}\mathrm{kg} / \mathrm{kg} \\
\text { waste }\end{array}$ & $0.0 E+O D$ & $0.0 E+00$ & $0.0 E+00$ & $0.0 E+00$ & $0.0 E+00$ & $0.0 E+\infty$ & $0.0 E+00$ \\
\hline Zinc (6) & $\mathrm{Zn}$ & $\begin{array}{l}\mathrm{kg} / \mathrm{kg} \\
\text { waste }\end{array}$ & 5.1E-0. & $3.4 \mathrm{E}-01$ & $5.1 \mathrm{E}-04$ & $2.4 \mathrm{E}-04$ & $1.8 \mathrm{E}-02$ & $8.8 E-03$ & $6.5 E-01$ \\
\hline Thallium (6) & $\mathrm{TI}$ & $\begin{array}{l}\mathrm{kg} / \mathrm{kg} \\
\text { waste }\end{array}$ & 7.1E-05 & $0.0 E+00$ & $0.0 \mathrm{E}+00$ & $0.0 \mathrm{E}+\infty 0$ & $0.0 E+\infty 0$ & $8.4 E-05$ & $0.0 \mathrm{E}+00$ \\
\hline Silicon (6) & si & $\begin{array}{l}\mathrm{kg} / \mathrm{kg} \\
\text { waste }\end{array}$ & 1.8E-04 & $0.0 E+\infty O$ & $0.0 E+00$ & $0.0 \mathrm{E}+00$ & $0.0 E+\infty O$ & $0.0 E+\infty$ & $0.0 \mathrm{E}+\infty 0$ \\
\hline Iron & $\mathrm{Fe}$ & $\begin{array}{l}\mathrm{kg} / \mathrm{kg} \\
\text { waste }\end{array}$ & $9.8 \mathrm{E}-01(3)$ & $1.1 \mathrm{E}-02(3)$ & & & & & \\
\hline Aluminium & Al & $\begin{array}{l}\mathrm{kg} / \mathrm{kg} \\
\text { waste }\end{array}$ & & $5.5 E-03(3)$ & & & & & \\
\hline Potassium & K & $\begin{array}{l}\mathrm{kg} / \mathrm{kg} \\
\text { waste }\end{array}$ & & & & & & $2.5 E-02(5)$ & $6.7 E-02(5)$ \\
\hline Sum wet mass & & $\begin{array}{l}\mathrm{kg} / \mathrm{kg} \\
\text { waste }\end{array}$ & 1.00 & 1.00 & 1.00 & 1.00 & $1 . \infty$ & 1.00 & 1.00 \\
\hline $\begin{array}{l}\text { Share of iron that is metallic/recyclable } \\
\text { (7) }\end{array}$ & & & 1 & o & o & o & o & o & o \\
\hline Share of carbon that is biogenic ( 7 ) & & & o & $a_{3}$ & o & o & 1 & o & o \\
\hline $\begin{array}{l}\text { Degradability in a municipal landfill } \\
\text { within } 100 \text { years }(\mathrm{X})(\mathrm{B})\end{array}$ & & & 0.3 & 0.3 & 1 & 4 & 1 & o & 3 \\
\hline
\end{tabular}

(1) From Almeida et al. (2006). Table 1. Due to the variation on anode moisture content the balance to the average total weight of the batteries was considered. (2) Estimated.

(3) Calculated as the difference to make 1 in the sum wet mass. In the anode collector the amount was partitioned between Fe ( $50 \%$ ) and Sn and $\mathrm{A}$ (25\% each)

(4) Composition calculated from the chemical formula PA - $\left(\mathrm{C}_{0} \mathrm{H}_{1}, \mathrm{ON}\right) n$; Paper $-\left(\mathrm{C}_{1} \mathrm{H}_{1} \mathrm{O}_{5}\right) n$; PVC $-\left(\mathrm{CH}_{2} \mathrm{CHC}\right) n$.

(5) From Almeida et al. (2006). Table 2. It was considered that $K$ is equally dissolved in the moisture of the cathode and anode.

(7) - rom Almeida et at. (2006), Table 2.

(B) Degradability estimated on landflling mo 
Table 4

Parameters used on the calculation of transfer coefficients for the landfilling modeling (Doka, 2009)

\begin{tabular}{lll}
\hline Element & $\begin{array}{l}\text { Release factor (\% of degraded } \\
\text { material that is emitted) }\end{array}$ & $\begin{array}{l}\text { \%gas (w\% of short-term } \\
\text { emissions to gas) }\end{array}$ \\
\hline $\mathrm{H}_{2} \mathrm{O}$ & 100 & 0 \\
$\mathrm{O}$ & 100 & 97.1 \\
$\mathrm{H}$ & 100 & 97.1 \\
$\mathrm{C}$ & 100 & 97.1 \\
$\mathrm{~S}$ & 43.8 & 14.9 \\
$\mathrm{~N}$ & 250 & 6.44 \\
$\mathrm{Cl}$ & 255 & 1.38 \\
$\mathrm{As}$ & 18 & 1.38 \\
$\mathrm{Cd}$ & 17.7 & 0.662 \\
$\mathrm{Co}$ & 32.2 & 0.025 \\
$\mathrm{Cr}$ & 1.14 & 0.025 \\
$\mathrm{Cu}$ & 0.49 & 0.029 \\
$\mathrm{Hg}$ & 9.59 & 28.6 \\
$\mathrm{Mn}$ & 115 & 0.025 \\
$\mathrm{Ni}$ & 5.82 & 0.025 \\
$\mathrm{~Pb}$ & 0.59 & 0.033 \\
$\mathrm{Sb}$ & 10.5 & 0.025 \\
$\mathrm{Sn}$ & 0.59 & 0.025 \\
$\mathrm{Zn}$ & 4.74 & 0.022 \\
$\mathrm{Tl}$ & 5.82 & 0.025 \\
$\mathrm{Si}$ & 5 & 0.025 \\
$\mathrm{Fe}$ & 1.37 & 0.025 \\
$\mathrm{Al}$ & 5 & 0.025 \\
$\mathrm{~K}$ & 73.1 & 0.025 \\
\hline
\end{tabular}

Table 5

Inputs, outputs and data source for the inventory from landfilling $1 \mathrm{~kg}$ of batteries. 


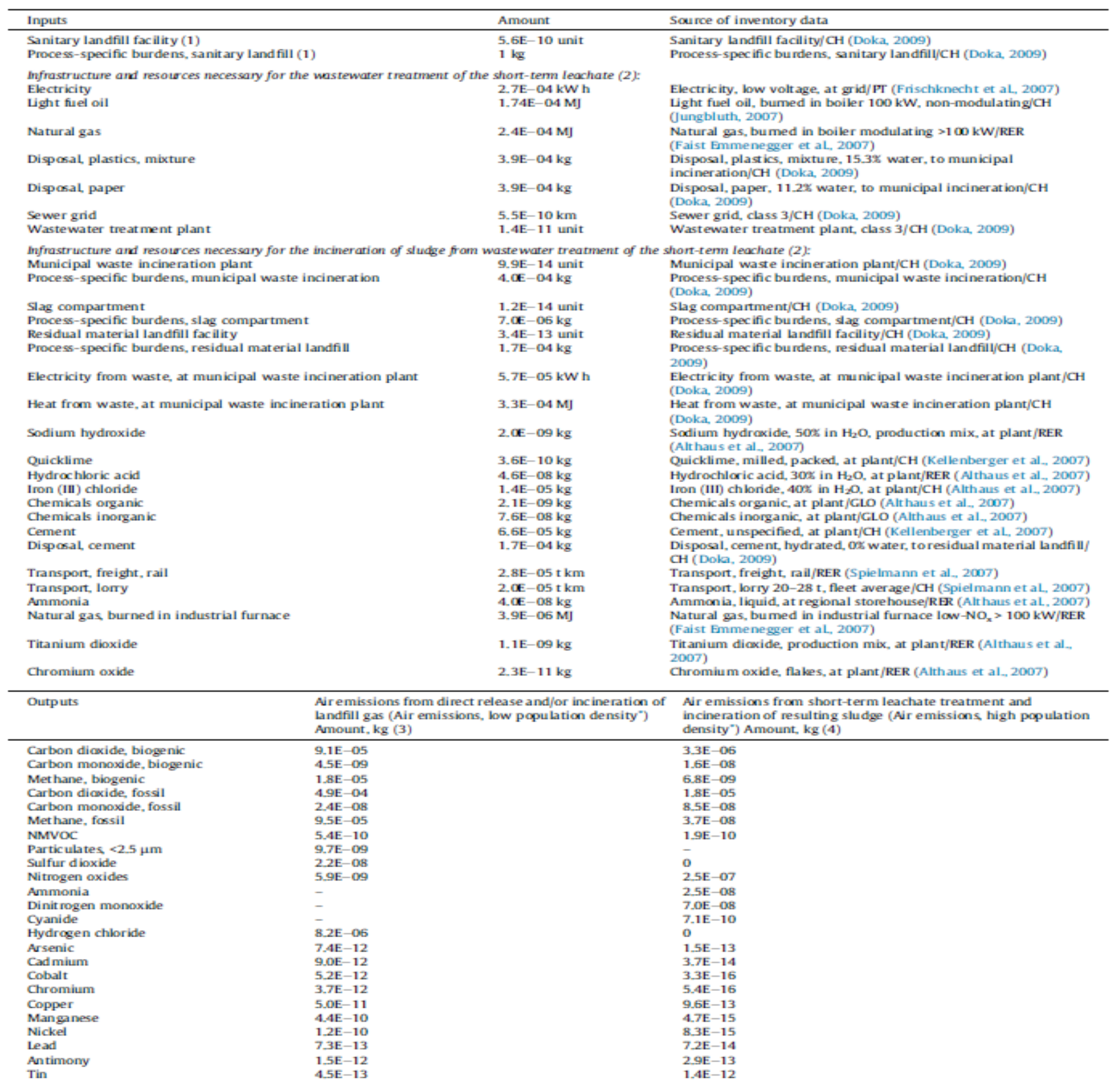




\begin{tabular}{|c|c|c|}
\hline Outputs & $\begin{array}{l}\text { Airemissions from direct release and/or incineration of } \\
\text { landfill gas (Air emissions, low population density") } \\
\text { Amount, } \mathrm{kg} \text { ( } 3 \text { ) }\end{array}$ & $\begin{array}{l}\text { Air emissions from short-term leachate treatment and } \\
\text { inc ineration of resulting slud ge (Air emissions, high population } \\
\text { density") Amount, } \mathrm{kg} \text { (4) }\end{array}$ \\
\hline Zinc & $4.3 \mathrm{E}-0 \mathrm{~B}$ & $22 \mathrm{E}-09$ \\
\hline Thallium & $6.2 \mathrm{E}-13$ & $1.2 \mathrm{E}-12$ \\
\hline Silicon & $1.3 \mathrm{E}-12$ & $1.2 E-11$ \\
\hline Iron & $20 E-09$ & $1.3 E-10$ \\
\hline Aluminum & 3. $8 \mathrm{E}-12$ & $2.3 \mathrm{E}-11$ \\
\hline Potassium m & $7.6 \mathrm{E}-08$ & 0 \\
\hline Outputs & $\begin{array}{l}\text { Water emissions from short-term leachate treat ment and } \\
\text { incineration of result ing slud ge (- }{ }^{-} \text {only from leachate } \\
\text { treatment) (Water emissions, niver") Amount, kg (4) }\end{array}$ & $\begin{array}{l}\text { Water emissions from long-term leachate (>100a) directly } \\
\text { from MSW landfill and indirectly via incineration of sludge } \\
\text { from leachate treatment ("- only from MSW long-term } \\
\text { leachate) (Water emissions, grou nd, long-term") Amount, kg } \\
\text { (5) }\end{array}$ \\
\hline BOD5, Biological Oxygen Demand & $1.5 \mathrm{E}-06$ & $29 \mathrm{E}-03$ \\
\hline COD, Chemical Oxygen Demand & 4.6E- 06 & $1.2 \mathrm{E}-02$ \\
\hline & 1.2E-06 & $1.1 \mathrm{E}-02$ \\
\hline $\begin{array}{l}\text { DOC, Dissolved Organic Carbon } \\
\text { Sulfate }\end{array}$ & $\begin{array}{l}1.1 \mathrm{E}-06 \\
1.9 \mathrm{E}-07 .\end{array}$ & $1.1 \mathrm{E}-02$ \\
\hline $\begin{array}{l}\text { Sumbare } \\
\text { Hydrogen sulfide }\end{array}$ & & $\begin{array}{l}1.7 \mathrm{E}-03^{-} \\
4.5 \mathrm{E}-05^{-}\end{array}$ \\
\hline Nitrogen & 3. $7 E-07$ & \\
\hline Ammonium, ion & $1.4 \mathrm{E}-05$ & $4.5 \mathrm{E}-\mathrm{OA}^{--}$ \\
\hline Nitrate & 5.0E-05 & 4.7E-05 \\
\hline Nitrite & $29 \mathrm{E}-07$ & $2.5 \mathrm{E}-05^{-}$ \\
\hline Nitrogen, organic bou nd & & $7,4 \mathrm{E}-04-$ \\
\hline Chloride & 5.7E-04- & $5.1 \mathrm{E}-03^{-}$ \\
\hline Arsenic, ion & $4.6 \mathrm{E}-10$ & $9.1 \mathrm{E}-07$ \\
\hline Cadmium, ion & 6. $8 \mathrm{E}-10$ & $2.6 \mathrm{E}-06$ \\
\hline Cobalt & $1.1 \mathrm{E}-08$ & $3.6 \mathrm{E}-0.05$ \\
\hline Chromium VI & $7.8 E-09$ & 1.8E-06 \\
\hline Copper, ion & 4.6E- 08 & $1.2 \mathrm{E}-02$ \\
\hline $\begin{array}{l}\text { Mercury } \\
\text { Manganese }\end{array}$ & ${ }_{9.0 E-07}^{\circ}$ & $\begin{array}{l}1.6 \mathrm{E}-0 \mathrm{07}- \\
22 \mathrm{E}-01\end{array}$ \\
\hline Nickel, ion & 3.0E-07 & $28 \mathrm{E}-01$ \\
\hline Lead & $24 \mathrm{E}-10$ & $5.0 \mathrm{E}-05$ \\
\hline Antimony & $4.0 E-09$ & $1.9 E-06$ \\
\hline Tin, ion & $7.5 \mathrm{E}-10$ & $1.0 E-04$ \\
\hline Zinc, ion & 5.9E-0. & $1.2 \mathrm{E}-01$ \\
\hline Thallium & $1.3 \mathrm{E}-09$ & 6.0E-05 \\
\hline Silicon & 3. $2 \mathrm{E}-10$ & $6.9 E-07$ \\
\hline Iron, ion & 4. $1 \mathrm{E}-06$ & $1.4 \mathrm{E}-02$ \\
\hline Aluminum & $9.2 E-10$ & 1.0E-O4 \\
\hline $\begin{array}{l}\text { Potassium, ion } \\
\text { Chromium, ion }\end{array}$ & $\begin{array}{l}\text { 3.0E-0.4- } \\
2.3 \mathrm{E}-11\end{array}$ & $2.7 E-02^{--}$ \\
\hline \multicolumn{2}{|l|}{ Outputs, Heat waste } & Amount, MJ \\
\hline \multicolumn{2}{|c|}{$\begin{array}{l}\text { Air emissions low population density - from direct } \\
\text { rele ase or incineration of landfill biogas }\end{array}$} & $9.2 \mathrm{E}-0.04(6)$ \\
\hline \multirow{2}{*}{\multicolumn{2}{|c|}{$\begin{array}{l}\text { Soil emissions, industrial - from short-term } \\
\text { decomposition of waste (0-100a) }\end{array}$}} & $3.8 \mathrm{E}-02(7)$ \\
\hline & & \\
\hline \multicolumn{2}{|c|}{$\begin{array}{l}\text { Water emissions, ground, long-term - from long- } \\
\text { term decomposition of waste (>100a) }\end{array}$} & $5.2(8)$ \\
\hline \multicolumn{2}{|c|}{$\begin{array}{l}\text { Air emissions high population density - from } \\
\text { incineration of sludge from short-term leachate } \\
\text { treat ment }\end{array}$} & $1.0 E-03(4)$ \\
\hline \multicolumn{2}{|c|}{$\begin{array}{l}\text { Water emissions, river - from incineration of sludge } \\
\text { from short-term leachate treatment }\end{array}$} & $1.3 E-04(4)$ \\
\hline
\end{tabular}

Outputs Amount, M]

Source of invent ory data

\begin{tabular}{lll} 
Electricity production & Amount, M] & Source orfinentory data \\
\hline & $2.5 \mathrm{E}-04(9)$ & Electricity. production mix/PT (Frischknecht et al_.2 2007)
\end{tabular}

(1) Infrastructure, resou roes and emissions process-specific for the landfill itself. Cakulated taking into account the amount of batteries to landfill (1 kg) and the capacity of the landfill (1,800,000 ton)

ant and composition of the leachate produced according to Doka (2000)

(3) Air emissions from direct release or incineration of landfill gas are determined by application of TK gas to the batteries composition. In the text (Section 3.2) the TK gas $33.3 \%$ in open flare and 66.72 for energy recovery (Table 1 ). For $\mathrm{C} S \mathrm{~S}$, $\mathrm{N}$ and $\mathrm{C}$ the following air emissions spectiation are considered:
(T)

a For $\mathrm{C}-\mathrm{CO}_{2}, \mathrm{CO}, \mathrm{CH}_{4}$, NMVOC and Particles. $\mathrm{CO}_{2}$ and $\mathrm{CH}_{4}$ emissions exist in both directly emitted and combusted gas; all the others only exist in the combusted gas. compound per $\mathrm{g}$ of $\mathrm{C}$ in the landfill raw gas or in combusted landfill gas respectively, obtained from literat ure:

For landfill raw gas (direct emission) the reported data are (Doka, 2009): $\mathrm{CO}_{2}-1.6 ; \mathrm{CH}_{4}-0.75 \mathrm{~g}$ of compound per $\mathrm{g}$ of C

- For combusted gas the reported data are (Doka, 2009): $\mathrm{CO}_{2}-3.7$; $\mathrm{CO}-3.1 \mathrm{E}-04$; $\mathrm{CH}_{4}-2.5 \mathrm{E}-05$; NMVOC - 5.9E-06; Particles (all assumed >2.5 $\mu \mathrm{m}$ ) - 1.0E-04 g of

- For $\mathrm{CO}_{2}$. CO and $\mathrm{CH}_{4}$ the fossil and the biogenic fractions are separately accounted for using the respective share of biogenic/fossil $\mathrm{C}$ in the degraded residue

b. For S- $\mathrm{SO}_{2}$; and for $\mathrm{Cl}-\mathrm{HCl}$; both are present in direct emitted and combusted gas. In the calculation, the weight increase due to the speciation to $\mathrm{SO}_{2}$ (2) and $\mathrm{HCl}$ (1.03)

is taken in to account. 
c. For $\mathrm{N}-\mathrm{NO}_{2}$; only present in the combusted gas The calculation is similar to the one explained for the C compounds using the content of $\mathrm{NO}_{2}$ perg of $\mathrm{N}$ in the combusted landfill gas equal to $8.5 \mathrm{E}-03$ (Doka, 2009).

(4) Emissions (water, air and heat) from short-term leachate treatment and incineration of resulting sludge were calculated from the amount and composition of the leachate produced: the amount of leachate is considered equal to $2.5 \mathrm{E}-03 \mathrm{~m}^{3}$ per $\mathrm{kg}$ of waste over the 100 years (Doka, 2009); the leachate composition was obtained by application of TK short-term leachate to the batteries composition. In the text (Section 32) the TK short-term leachate calculation is expla ined.

For $\mathrm{S}$ and $\mathrm{N}$ the following leachate speciation are considered:

For $\mathrm{S}-\mathrm{SO}$ it is isonsidered all the Semitted as Sulfate.

b. For $\mathrm{N}-\mathrm{NH}_{4}(31.78)$, $\mathrm{Norg}(66.68)$, $\mathrm{NO}_{2}(0.78)$ and $\mathrm{NO}_{3}(1.08)$; the share of the total $\mathrm{N}$ in each leachate specie were obtained from literature (Dola, 2009).

The models used for both the leachate treatment and the incineration of resulting sludge processes are from Doka (2009) without any change and so the calculations are not detailed here, In that model, that contains not only the direct burdens from the leachate treatment itself but also the burdens from sludge disposal (incineration and landfilling of resulting ash) individual factors describing the burdens created from $1 \mathrm{~kg}$ of pollut ant in $1 \mathrm{~m}^{3}$ wastewater are calculated for each pollutant in the leachate. (5) Emissions from long-term leachate ( $>100 a$ ) directly from MSW landfill were obtained by application of TK long-term leachate to the batteries composition. In the text (Section 3.2) the TK long-tem leachate calculation is explained.

For $\mathrm{C}, \mathrm{S}$ and $\mathrm{N}$ the following leachate speciation are considered:

a. For $\mathrm{C}$ - The BOD, and COD emissions were determined from TOC using the respective ratios ( $\sim 2.26$ for BOD5 and $\sim 1.1$ for COD, from Doka, 2009)

b. For $\mathrm{S}-\mathrm{SO}_{4}(93.1 \%)$ and $\mathrm{H}_{2} \mathrm{~S}(6.98)$.

c. For $\mathrm{N}-\mathrm{NH}_{4}(31.7 x)$, $\mathrm{Norg}(66.68), \mathrm{NO}_{2}(0.78)$ and $\mathrm{NO}_{3}(1.08)$.

The share of the total $\mathrm{S}$ and $\mathrm{N}$ in each leachate specie were obtained from literature (Doka, 2009).

The emissions resulting from the incineration of sludge from leachate treatment were obtained as explained in the end of note 4.

(6) Heat produced in carbon combusted: obtained from the product of $\mathrm{C}_{\text {as }} \mathrm{CH}_{4}$ in the combusted gas and the energy content in C considered equal to $40 \mathrm{My} / \mathrm{kg}$ (Doka, 2009). The wasted parte is given by the share of gas combusted in open flare (33.38).

(7) This is the reaming short-term heat waste: Obtained from the heat liberated in 100 years, discounting the Carbon combusted (note 7) and the $\mathrm{C}^{2}$ directly emitted as $\mathrm{CH}_{4}$ (note 4). The heat liberated in 100 years is calculated as the product of the upper heating value of the batteries and the share of heat content degraded in 100 years.

(8) This is the remaining long-term heat waste, obtained from the upper heating value of the batteries and discounting the heat liberated in 100 years (see note 7 ).

(9) Calculated from the share of heat produced in carbon combusted that is 66.7\% of the total (note 7) and using an Efficiency of conversion of 13.5\% (Doka, 2009).

Environmental compartment (see text, section 4). 
Table 6. Transfer coefficients used in the incineration modeling.

\begin{tabular}{llll}
\hline \multirow{2}{*}{ Element } & \multicolumn{2}{l}{ Transfer coefficients (\%) } & Bottom ash \\
\cline { 2 - 4 } & Fly ash & Air & 98.46 \\
\hline $\mathrm{S}(1)$ & 1.40 & 0.132 & 65.27 \\
$\mathrm{Cl}(1)$ & 31.8 & 2.93 & 99.94 \\
$\mathrm{As}(1)$ & 0.0336 & 0.0288 & 89.74 \\
$\mathrm{Cd}(1)$ & 10.2 & 0.0534 & 98.91 \\
$\mathrm{Co}(1)$ & 1.08 & 0.00961 & 89.39 \\
$\mathrm{Cr}(1)$ & $10.0^{*}$ & 0.614 & 99.97 \\
$\mathrm{Cu}(1)$ & 0.0313 & 0.00140 & 99.78 \\
$\mathrm{Fe}(1)$ & 0.223 & 0 & 94.44 \\
$\mathrm{Hg}(1)$ & 1.46 & 4.11 & 99.96 \\
$\mathrm{Mn}(1)$ & 0.0355 & 0 & 99.92 \\
$\mathrm{Ni}(1)$ & 0.0801 & 0.00010 & 69.74 \\
$\mathrm{~Pb}(1)$ & 29.2 & 1.10 & 99.63 \\
$\mathrm{Sb}(1)$ & 0.289 & 0.0839 & 99.27 \\
$\mathrm{Tl}(1)$ & 0.712 & 0.0212 & 93.42 \\
$\mathrm{Zn}(1)$ & 6.53 & 0.0503 & 1.55 \\
$\mathrm{C}(2)$ & 0.30 & 98.15 & 0 \\
$\mathrm{H}$ & 0 & 100 & 1.0 \\
$\mathrm{~N}(2)$ & 0 & 99.0 & 3.4 \\
$\mathrm{O}(2)$ & 0 & 96.6 & 62.9 \\
$\mathrm{~K}(2)$ & 36.9 & 0.2 & \\
\hline
\end{tabular}

(1) Obtained from laboratory incineration tests (Almeida et al., 2009). The values obtained for the furnace were considered "fly ash" and the ones for the bubbler flask 1 and 2 were considered "air emissions". The values for "bottom ash" were obtained by balance.

(2) Values obtained from Koehler et al. (2011), Supporting information, Table 10. The values for $\mathrm{C}$ already take into account the total transfer to the bottom ash of the $\mathrm{C}$ from the inert components of the batteries. For the remaining elements $\mathrm{N}, \mathrm{O}$ and $\mathrm{K}$ this situation does not arise because they only exist in the burnable components.

As there were no laboratory quantified emissions for $\mathrm{Al}, \mathrm{Si}$ and $\mathrm{Sn}$, the transfer coefficients for inert components were considered since these elements are only present in that type of components.

The $\mathrm{Cr}$ transfer coefficient for "fly ash" was corrected taking into account the results discussion in Almeida et al. (2009) and by comparison with other published values. 
Table 7. Transfer coefficients used in modeling bottom and fly ash landfilling processes (Doka, 2009)

\begin{tabular}{|c|c|c|c|c|}
\hline \multirow[t]{2}{*}{ Element } & \multicolumn{2}{|c|}{$\begin{array}{l}\text { Transfer coefficients (\%) } \\
\text { bottom ash }\end{array}$} & \multicolumn{2}{|c|}{ Transfer coefficients (\%) fly ash } \\
\hline & $\begin{array}{l}\text { Short-term } \\
100 \text { years }\end{array}$ & $\begin{array}{l}\text { Long-term } \\
>100 \text { years }\end{array}$ & $\begin{array}{l}\text { Short-term } \\
100 \text { years }\end{array}$ & $\begin{array}{l}\text { Long-term } \\
>100 \text { years }\end{array}$ \\
\hline C & 0.18 & 99.82 & 0.108 & 64.625 \\
\hline S & 9.12 & 90.88 & 10.73 & 89.27 \\
\hline $\mathrm{N}$ & 18.88 & 81.12 & 18.88 & 81.12 \\
\hline $\mathrm{Cl}$ & 86.38 & 13.62 & 28.60 & 71.40 \\
\hline As & 0.150 & 99.85 & 100.0 & 0 \\
\hline $\mathrm{Cd}$ & 0.051 & 99.949 & 0.001 & 0.679 \\
\hline Co & 0.014 & 99.986 & 0.029 & 17.096 \\
\hline $\mathrm{Cr}$ & 0.003 & 0.654 & 6.01 & 18.99 \\
\hline $\mathrm{Cu}$ & 0.003 & 99.997 & 0.006 & 3.849 \\
\hline $\mathrm{Hg}$ & 2.62 & 97.38 & 0.008 & 4.720 \\
\hline Mn & 0.005 & 99.995 & 0.001 & 0.826 \\
\hline $\mathrm{Ni}$ & 0.063 & 99.937 & 0.060 & 36.204 \\
\hline $\mathrm{Pb}$ & 0.002 & 99.998 & 0.001 & 0.519 \\
\hline Sb & 0.067 & 14.471 & 35.27 & 64.73 \\
\hline Sn & 0.002 & 99.442 & 0.003 & 1.895 \\
\hline $\mathrm{Zn}$ & 0.003 & 99.997 & 0.002 & 1.226 \\
\hline $\mathrm{Tl}$ & 0.063 & 99.937 & 0.060 & 36.204 \\
\hline $\mathrm{Si}$ & 0.004 & 0.856 & 0.225 & 99.775 \\
\hline $\mathrm{Fe}$ & 0.001 & 52.019 & 0.001 & 0.501 \\
\hline $\mathrm{Ca}$ & 0.436 & 99.564 & 0.015 & 9.036 \\
\hline Al & 0.001 & 81.686 & 0.050 & 29.685 \\
\hline $\mathrm{K}$ & 12.085 & 87.915 & 28.19 & 71.81 \\
\hline
\end{tabular}


Table 8. Inputs, outputs and data source for the inventory of $1 \mathrm{~kg}$ batteries incineration.

\begin{tabular}{|c|c|c|c|}
\hline Inputs & Amount & Source of inventory data & \\
\hline Municipal waste incineration plant (1) & $2.5 \mathrm{E}-10$ unit & Municipal waste incineration plant/CH (Doka, 2009) & \\
\hline Bottom ash landfill (2) & $9.1 \mathrm{E}-10$ unit & Slag compartment/CH (Doka, 2009) & \\
\hline $\begin{array}{l}\text { Process-specific burdens from the } \\
\text { bottom ash landfill ( } 3 \text { ) }\end{array}$ & $5.1 \mathrm{E}-01 \mathrm{~kg}$ & $\begin{array}{l}\text { Process-specific burdens, slag compartment/CH (Doka, } \\
\text { 2009) }\end{array}$ & \\
\hline Fly ash landfill (4) & 5.7E-11 unit & Residual material landfill facility/CH (Doka, 2009) & \\
\hline $\begin{array}{l}\text { Process-specific burdens from the fly ash } \\
\text { landfill (5) }\end{array}$ & $2.7 \mathrm{E}-02 \mathrm{~kg}$ & $\begin{array}{l}\text { Process-specific burdens, residual material landfill/CH } \\
\text { (Doka, 2009) }\end{array}$ & \\
\hline Cement (6) & $1.1 \mathrm{E}-02 \mathrm{~kg}$ & Cement, unspecified, at plant/CH (Kellenberger et al., 2007) & \\
\hline $\begin{array}{l}\text { Disposal of cement and water used for fly } \\
\text { ash solidification (7) }\end{array}$ & $2.7 \mathrm{E}-02 \mathrm{~kg}$ & $\begin{array}{l}\text { Disposal, cement, hydrated, } 0 \% \text { water, to residual material } \\
\text { landfill/CH (Doka, 2009) }\end{array}$ & \\
\hline Transport, lorry (8) & $6.8 \mathrm{E}-03 \mathrm{t} \mathrm{km}$ & $\begin{array}{l}\text { Transport, lorry } 16-32 \text { t, EURO4/RER (Spielmann et al., } \\
\text { 2007) }\end{array}$ & \\
\hline Ammonia - waste and process specific (9) & $2.6 \mathrm{E}-04 \mathrm{~kg}$ and $3.8 \mathrm{E}-04 \mathrm{~kg}$ & $\begin{array}{l}\text { Ammonia, liquid, at regional storehouse/RER (Althaus } \\
\text { et al., 2007) }\end{array}$ & \\
\hline Lime, $\mathrm{Ca}(\mathrm{OH}) 2(10)$ & $2.6 \mathrm{E}-04 \mathrm{~kg}$ & $\begin{array}{l}\text { Lime, hydrated, packed, at plant/CH (Kellenberger et al., } \\
\text { 2007) }\end{array}$ & \\
\hline Activated carbon (11) & $4.3 \mathrm{E}-04 \mathrm{~kg}$ & Charcoal, at plant/GLO (Werner et al., 2007) & \\
\hline Water (12) & $3.3 \mathrm{E}-011$ & Water, decarbonised, at plant/RER (Althaus et al., 2007) & \\
\hline Natural gas (13) & 3.3E-02 MJ & $\begin{array}{l}\text { Natural gas, high pressure, at consumer/RER (Faist } \\
\text { Emmenegger et al., 2007) }\end{array}$ & \\
\hline Diesel (14) & $1.3 \mathrm{E}-05 \mathrm{~kg}$ & Diesel, at regional storage/RER (Jungbluth, 2007) & \\
\hline $\begin{array}{l}\text { Outputs - Air emissions from } \\
\text { incineration (Air emissions, high } \\
\text { population density }{ }^{*} \text { ) }\end{array}$ & Amount, kg & $\begin{array}{l}\text { Outputs, cont. - Air emissions from incineration (Air } \\
\text { emissions, high population density }{ }^{\text {) }}\end{array}$ & $\begin{array}{l}\text { Amount, } \\
\mathrm{kg}\end{array}$ \\
\hline
\end{tabular}




\begin{tabular}{|c|c|c|c|}
\hline NMVOC (15) & $4.6 \mathrm{E}-06$ & Dinitrogen monoxide (24) & $1.7 \mathrm{E}-06$ \\
\hline Particulates <2.5 (16) & $8.1 \mathrm{E}-06$ & Hydrogen chloride (25) & $5.1 \mathrm{E}-06$ \\
\hline Particulates $2.5-10(16)$ & $4.1 \mathrm{E}-08$ & Arsenic (26) & $2.6 \mathrm{E}-10$ \\
\hline Dioxins (17) & $3.3 \mathrm{E}-14$ & Cadmium (27) & $1.4 \mathrm{E}-09$ \\
\hline Nitrogen oxides (thermal) (18) & $1.8 \mathrm{E}-04$ & Cobalt (26) & $3.5 \mathrm{E}-09$ \\
\hline Ammonia (thermal) (19) & $8.8 \mathrm{E}-07$ & Chromium (28) & $2.5 \mathrm{E}-06$ \\
\hline Carbon monoxide, biogenic (20) & $3.1 \mathrm{E}-06$ & Copper (26) & $1.7 \mathrm{E}-07$ \\
\hline Carbon monoxide, fossil (20) & $3.2 \mathrm{E}-05$ & Mercury (29) & $6.6 \mathrm{E}-09$ \\
\hline Methane, biogenic (21) & $5.5 \mathrm{E}-07$ & Nickel (26) & $2.8 \mathrm{E}-09$ \\
\hline Methane, fossil (21) & $5.7 \mathrm{E}-06$ & Lead (26) & $5.6 \mathrm{E}-07$ \\
\hline Carbon dioxide, biogenic (22) & $1.4 \mathrm{E}-02$ & Antimony (27) & $1.6 \mathrm{E}-08$ \\
\hline Carbon dioxide, fossil (22) & $1.4 \mathrm{E}-01$ & Zinc (26) & $7.3 \mathrm{E}-05$ \\
\hline Sulfur dioxide (23) & $2.1 \mathrm{E}-07$ & Thallium (26) & $1.3 \mathrm{E}-08$ \\
\hline Nitrogen oxides (fuel) (24) & $1.3 \mathrm{E}-04$ & Potassium (30) & $5.5 \mathrm{E}-05$ \\
\hline Ammonia (fuel) (24) & $6.0 \mathrm{E}-07$ & Heat, waste (31) & $4.3 \mathrm{MJ}$ \\
\hline Outputs & $\begin{array}{l}\text { Water short-term emissions from bottom ash and fly } \\
\text { ash landfill (Water emissions, river }{ }^{*} \text { ) Amount, kg }\end{array}$ & $\begin{array}{l}\text { Water long-term emissions from bottom ash and fly ash } \\
\text { landfill (Water emissions, ground, long-term*) Amount, kg }\end{array}$ & \\
\hline BOD5, Biological Oxygen Demand (32) & $1.2 \mathrm{E}-06$ & $7.0 \mathrm{E}-04$ & \\
\hline COD, Chemical Oxygen Demand (32) & $3.7 \mathrm{E}-06$ & $2.1 \mathrm{E}-03$ & \\
\hline TOC, Total Organic Carbon (32) & $1.5 \mathrm{E}-06$ & $8.5 \mathrm{E}-04$ & \\
\hline DOC, Dissolved Organic Carbon (32) & $1.5 \mathrm{E}-06$ & $8.5 \mathrm{E}-04$ & \\
\hline Sulfate (33) & $1.7 \mathrm{E}-04$ & $1.7 \mathrm{E}-03$ & \\
\hline Nitrate (34) & $9.5 \mathrm{E}-06$ & $4.1 \mathrm{E}-05$ & \\
\hline Chloride (35) & $3.8 \mathrm{E}-03$ & $1.9 \mathrm{E}-03$ & \\
\hline Arsenic, ion (36) & $1.7 \mathrm{E}-09$ & $9.1 \mathrm{E}-07$ & \\
\hline Cadmium, ion (36) & $1.2 \mathrm{E}-09$ & $2.3 \mathrm{E}-06$ & \\
\hline Cobalt (36) & $5.1 \mathrm{E}-09$ & $3.6 \mathrm{E}-05$ & \\
\hline Chromium VI (36) & $2.4 \mathrm{E}-06$ & $1.0 \mathrm{E}-05$ & \\
\hline Copper, ion (36) & $4.2 \mathrm{E}-07$ & $1.2 \mathrm{E}-02$ & \\
\hline Mercury (36) & $4.0 \mathrm{E}-09$ & $1.5 \mathrm{E}-07$ & \\
\hline Manganese (36) & $1.2 \mathrm{E}-05$ & $2.3 \mathrm{E}-01$ & \\
\hline Nickel, ion (36) & $1.8 \mathrm{E}-06$ & $2.8 \mathrm{E}-03$ & \\
\hline Lead (36) & $7.7 \mathrm{E}-10$ & $3.5 \mathrm{E}-05$ & \\
\hline Antimony (36) & $3.2 \mathrm{E}-08$ & $2.7 \mathrm{E}-06$ & \\
\hline Zinc, ion (36) & $4.2 \mathrm{E}-06$ & $1.4 \mathrm{E}-01$ & \\
\hline Thallium (36) & $3.8 \mathrm{E}-08$ & $6.0 \mathrm{E}-05$ & \\
\hline Tin, ion (37) & $1.6 \mathrm{E}-09$ & $1.0 \mathrm{E}-04$ & \\
\hline Silicon (37) & $1.3 \mathrm{E}-09$ & $3.1 \mathrm{E}-07$ & \\
\hline Aluminum (37) & $1.3 \mathrm{E}-09$ & $8.3 \mathrm{E}-05$ & \\
\hline Iron, ion (38) & $3.6 \mathrm{E}-09$ & $2.2 \mathrm{E}-06$ & \\
\hline Calcium (39) & $2.1 \mathrm{E}-08$ & $1.3 \mathrm{E}-05$ & \\
\hline Potassium, ion (40) & $4.9 \mathrm{E}-03$ & $2.2 \mathrm{E}-02$ & \\
\hline Heat, waste (31) & $0.30 \mathrm{MJ}$ & & \\
\hline Outputs - energy and materials recovered & Amount & Source of inventory data & \\
\hline Electric energy (41) & $0.80 \mathrm{MJ}$ & Electricity, production mix/PT (Frischknecht et al., 2007) & \\
\hline Fe from bottom ash descrapping (42) & $0.20 \mathrm{~kg}$ & Iron scrap, at plant/RER (Classen et al., 2009) & \\
\hline
\end{tabular}

* Environmental compartment (see text, Section 4). 